Atmos. Chem. Phys., 13, 11121-11140, 2013

www.atmos-chem-phys.net/13/11121/2013/

doi:10.5194/acp-13-11121-2013

(c) Author(s) 2013. CC Attribution 3.0 License.

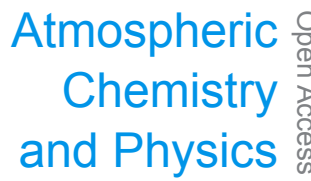

\title{
Effect of chemical structure on secondary organic aerosol formation from $\mathrm{C}_{12}$ alkanes
}

\author{
L. D. Yee ${ }^{1, *}$, J. S. Craven ${ }^{2}$, C. L. Loza ${ }^{2}$, K. A. Schilling ${ }^{2}$, N. L. Ng ${ }^{3}$, M. R. Canagaratna ${ }^{4}$, P. J. Ziemann ${ }^{5}$, \\ R. C. Flagan ${ }^{2,1}$, and J. H. Seinfeld ${ }^{2,1}$ \\ ${ }^{1}$ Division of Engineering and Applied Science, California Institute of Technology, Pasadena, California, USA \\ ${ }^{2}$ Division of Chemistry and Chemical Engineering, California Institute of Technology, Pasadena, California, USA \\ ${ }^{3}$ School of Chemical and Biomolecular Engineering and School of Earth and Atmospheric Sciences, Georgia Institute of \\ Technology, Atlanta, Georgia, USA \\ ${ }^{4}$ Aerodyne Research, Inc., Billerica, Massachusetts, USA \\ ${ }^{5}$ Air Pollution Research Center, Department of Environmental Sciences, and Environmental Toxicology Graduate Program, \\ University of California, Riverside, California, USA \\ *now at: Department of Environmental Science, Policy and Management, University of California, Berkeley, California, USA
}

Correspondence to: J. H. Seinfeld (seinfeld@ caltech.edu)

Received: 5 April 2013 - Published in Atmos. Chem. Phys. Discuss.: 24 April 2013

Revised: 17 September 2013 - Accepted: 11 October 2013 - Published: 15 November 2013

\begin{abstract}
The secondary organic aerosol (SOA) formation from four $\mathrm{C}_{12}$ alkanes (n-dodecane, 2-methylundecane, hexylcyclohexane, and cyclododecane) is studied in the Caltech Environmental Chamber under low- $\mathrm{NO}_{\mathrm{x}}$ conditions, in which the principal fate of the peroxy radical formed in the initial $\mathrm{OH}$ reaction is reaction with $\mathrm{HO}_{2}$. Simultaneous gas- and particle-phase measurements elucidate the effect of alkane structure on the chemical mechanisms underlying SOA growth. Reaction of branched structures leads to fragmentation and more volatile products, while cyclic structures are subject to faster oxidation and lead to less volatile products. Product identifications reveal that particle-phase reactions involving peroxyhemiacetal formation from several multifunctional hydroperoxide species are key components of initial SOA growth in all four systems. The continued chemical evolution of the particle-phase is structuredependent, with 2-methylundecane SOA formation exhibiting the least extent of chemical processing and cyclododecane SOA achieving sustained growth with the greatest variety of chemical pathways. The extent of chemical development is not necessarily reflected in the oxygen to carbon $(\mathrm{O}: \mathrm{C})$ ratio of the aerosol as cyclododecane achieves the lowest $\mathrm{O}: \mathrm{C}$, just above 0.2 , by the end of the experiment and hexylcyclohexane the highest, approaching 0.35.
\end{abstract}

\section{Introduction}

Long-chain alkanes constitute a significant component of the unresolved complex mixture (UCM) in motor vehicle fuel sources and its combustion products (Schauer et al., 1999, 2002) and are a potential source of atmospheric secondary organic aerosol (SOA) formation (Robinson et al., 2007). However, the extent of SOA formation from atmospheric alkane photooxidation remains uncertain (Bahreini et al., 2012; Gentner et al., 2012). Each fuel type (e.g., gasoline vs. diesel) has different distributions of alkane chain length and structure in terms of straight-chain, branched, cyclic, and cyclic + branched conformations (Schauer et al., 1999, 2002; Isaacman et al., 2012; Gentner et al., 2012). This variety in structure leads to chemical differences in the processes leading to SOA formation, which have been the subject of extensive laboratory studies (Lim and Ziemann, 2005; Lipsky and Robinson, 2006; Lim and Ziemann, 2009a, b, c; Presto et al., 2009, 2010; Nakao et al., 2011; Lambe et al., 2012; Tkacik et al., 2012) and modeling efforts (Jordan et al., 2008; Pye and Pouliot, 2012; Zhang and Seinfeld, 2013; Aumont et al., 2012; Cappa et al., 2013).

Gas-phase chemical mechanisms for the $\mathrm{OH}$-initiated oxidation of alkanes in the presence of $\mathrm{NO}_{\mathrm{x}}$ have been studied (Atkinson, 1994, 1997; Atkinson and Arey, 2003; Atkinson 
Table 1. $\mathrm{C}_{12}$ compounds studied.

Compound
cyclododecane
$\begin{aligned} & \text { a Using EVAPORATION (Compernolle et al., 2011) } \\ & \text { bexylcyclohexane }\end{aligned}$ - Calculated using relative rate from $n$-dodecane $k_{\mathrm{OH}}$ in MCM (Jenkin et al., 1997).

et al., 2008). Many aspects of key particle-phase reactions for these species have also been explored (Aschmann et al., 2003; Dibble, 2007; Lim and Ziemann, 2009c). The prevailing level of $\mathrm{NO}_{\mathrm{x}}$ is fundamental in atmospheric oxidation chemistry, as it controls, among other steps, the fate of the alkyl peroxy radical $\left(\mathrm{RO}_{2}\right)$ formed in the initial $\mathrm{OH}$-organic reaction. The designation, high- and low- $\mathrm{NO}_{\mathrm{x}}$, refer to conditions in which the $\mathrm{RO}_{2}$ fate is predominantly $\mathrm{RO}_{2}+\mathrm{NO}$ and $\mathrm{RO}_{2}+\mathrm{HO}_{2}$, respectively. These cases represent idealizations of actual atmospheric conditions, but they allow isolation of the mechanistic pathways leading to SOA formation in the two cases.

We focus here on the low- $\mathrm{NO}_{\mathrm{x}}$ oxidation mechanisms of four $\mathrm{C}_{12}$ alkanes ( $n$-dodecane, 2-methylundecane, hexylcyclohexane, and cyclododecane) (Table 1). The $\mathrm{C}_{12}$ alkane system is a prototype for relatively long alkanes, which are characterized by side chains and cyclic structure in addition to a linear structure. The distribution of oxidation products comprise a variety of functionalizations (hydroperoxy, hydroxyl, ketone, aldehyde, carboxylic acid, and peracid). Detailed study of the $\mathrm{C}_{12}$ system affords insight into the effect of alkane structure on the multigeneration gas-phase oxidation and particle-phase chemistry that leads to SOA formation.

This study builds on the previous work on the $n$-dodecane low- $\mathrm{NO}_{\mathrm{x}}$ system (Yee et al., 2012; Craven et al., 2012) employing complementary gas- (chemical ionization mass spectrometry) and particle-phase measurements (Aerodyne high-resolution time-of-flight aerosol mass spectrometry). Those studies revealed that peroxyhemiacetals are likely major components of the organic aerosol at initial growth. This was hypothesized via comparison of time trends of key gasand particle-phase ion tracers that showed initial SOA growth to be coincident with gas-phase aldehyde formation in the system, which can react with an available multifunctional hydroperoxide to form a peroxyhemiacetal (PHA). Of special interest in this study is the identification of and incorporation of multifunctional hydroperoxides in the aerosol via such accretion reactions as well as the chemical evolution of the aerosol as it ages.
Increasing evidence of accretion reactions observed in laboratory (Gao et al., 2004b, a; Kalberer, 2004; Surratt et al., 2010) and field measurements (Kalberer et al., 2006) suggest that these reactions are critical for understanding SOA formation chemistry (DePalma et al., 2013). PHA and peroxide formation have been observed in previous laboratory studies (Tobias et al., 2000; Tobias and Ziemann, 2000) and are relevant to consider in SOA formation from biogenics (Docherty et al., 2005; Capouet et al., 2008; Surratt et al., 2007), and aromatic systems (Johnson et al., 2005; Sato et al., 2007). Modeling studies including Capouet et al. (2008) and Johnson et al. (2005) show that parameterizations of laboratory SOA formation are improved if low volatility, high molecular weight product (PHA) formation is included. Modeling by Pye and Pouliot (2012) shows that alkanes are likely to contribute greater SOA mass concentrations than polyaromatic hydrocarbons and about half of this SOA formation could be from oligomers.

Most accretion reactions are not traditionally treated in modeling of atmospheric chemistry, mostly because the chemical pathways are not well-constrained by molecular level measurements. The current study provides measurements that elucidate PHA formation pathways in these alkane systems and data that can be used for modeling particlephase chemical processes. For example, Shiraiwa et al. (2013) found that the observed evolution of the particle size distribution in $n$-dodecane oxidation under low- $\mathrm{NO}_{\mathrm{x}}$ conditions could only be reasonably simulated when including kinetically-limited growth processes in the form of particlephase reactions (i.e., PHA formation). Additional controlled studies, like those described in this work, can provide a framework for modeling additional particle-phase reactions that provide insight into the controlling processes of SOA growth. 


\section{Experimental section}

\subsection{Chamber experiments}

The experiments in this study were conducted using the experimental protocols and controls as discussed in Yee et al. (2012) and Craven et al. (2012). The experiments and conditions are given in Table 2 . The $n$-dodecane experiments are the same as those presented in Yee et al. (2012) and Craven et al. (2012), and are used here for additional analyses and comparisons to the other $\mathrm{C}_{12}$ structures.

Experiments were conducted in the dual $28 \mathrm{~m}^{3}$ Caltech Environmental Chambers (Cocker et al., 2001; Keywood et al., 2004). The chambers were flushed for at least $24 \mathrm{~h}$ with dry purified air between experiments, resulting in particle number and volume concentrations $<100 \mathrm{~cm}^{-3}$ and $<0.1 \mu \mathrm{m}^{3} \mathrm{~cm}^{-3}$, respectively. Particle number concentration and size distributions were measured using a coupled differential mobility analyzer (DMA, TSI model 3081) and condensation particle counter (TSI Model 3010). Hydroxyl radicals were generated by photolysis of $\mathrm{H}_{2} \mathrm{O}_{2}$. Experiments began with slow injection of $280 \mu \mathrm{L}$ of a $50 \%$ aqueous $\mathrm{H}_{2} \mathrm{O}_{2}$ solution in a glass trap submerged in a warm water bath at $35-38^{\circ} \mathrm{C}$, via a $5 \mathrm{~L} \mathrm{~min}^{-1}$ flow of pure air. The chamber was then seeded with atomized $0.015 \mathrm{M}$ aqueous ammonium sulfate solution to achieve a target initial seed volume of $\sim 10$ $15 \mu^{3} \mathrm{~cm}^{-3}$. Subsequently, the hydrocarbon was injected by delivering the appropriate liquid volume or solid mass amount for the desired chamber concentration into a glass bulb, gently heating the glass bulb, and flowing $5 \mathrm{~L} \mathrm{~min}^{-1}$ of pure air over the hydrocarbon until evaporation was complete.

Temperature $(T)$, relative humidity $(\mathrm{RH})$, and concentrations of $\mathrm{O}_{3}, \mathrm{NO}$, and $\mathrm{NO}_{\mathrm{x}}$ were continuously monitored. Experiments were run at temperatures ranging from $23-26^{\circ} \mathrm{C}$ after an initial rise from $20^{\circ} \mathrm{C}$ upon irradiation. $\mathrm{RH}$ remained below $10 \%$ for all experiments except for the cyclododecane $36 \mathrm{~h}$ experiment in which $\mathrm{RH}$ rose to about $20 \%$ in the last six hours. NO levels remained below the $5 \mathrm{ppb}_{\mathrm{v}}$ lower detection limit of the analyzer (Horiba, APNA 360) and measured $\mathrm{NO}_{2}$ levels remained below $7 \mathrm{ppb}_{\mathrm{v}}$ after irradiation began.

\subsection{Gas- and particle-phase measurements}

Hydrocarbon concentration was continuously monitored by gas chromatograph-flame ionization detection (GC-FID) by taking $1.3 \mathrm{~L}$ samples of chamber air on Tenax adsorbent. The cartridge was loaded into the GC-FID (Agilent 6890N), desorbed, and injected onto an HP-5 column $(15 \mathrm{~m} \times 0.53 \mathrm{~mm}$ ID $\times 1.5 \mu \mathrm{m}$ thickness, Hewlett-Packard).

Gas-phase oxidation products were monitored using a chemical ionization mass spectrometer (CIMS), consisting of a custom-modified Varian 1200 triple quadrupole mass spectrometer (Crounse et al., 2006; Paulot et al., 2009; St. Clair et al., 2010). Briefly, the instrument was operated in neg- ative mode with $\mathrm{CF}_{3} \mathrm{OOCF}_{3}$ reagent gas, generating cluster products from the analyte at $\left[\mathrm{X} \cdot \mathrm{CF}_{3} \mathrm{O}\right]^{-}$and $\mathrm{F}$ transfer products at $[\mathrm{X} \cdot \mathrm{F}]^{-}$. The cluster product tends to occur when the analyte, $\mathrm{X}$, is a hydroperoxide or weakly acidic compound. The transfer product dominates for more strongly acidic compounds. Several carboxylic acids are present in both ionizations, and are therefore reported as the sum of the two products when used. The CIMS cannot detect ketones and aldehydes in this mode unless a molecule is additionallyfunctionalized with hydroperoxy or sufficient acidic groups (e.g., hydroxy, carboxyl) that it is sensitive to. The negative mode mass scan range was $m / z$ 50-300. Positive mode ionization utilizes water as the reagent gas and results in ion clusters of the form $\left[\mathrm{X} \cdot\left(\mathrm{H}_{2} \mathrm{O}\right)_{n} \mathrm{H}\right]^{+}$. The positive mode mass scan ranged from $\mathrm{m} / \mathrm{z}, 50$ to 200 . The gas-phase analyses presented here assume that the CIMS sensitivity to certain functionalized species within the same mode of operation are comparable despite differences in structure (straight, branched, cyclic + branched, cyclic).

Due to mid-project tuning shifts in the positive mode operation, the ions monitored were not those expected from the ionization of proposed products. The reported ions are those as monitored during the project, though the proposed ion assignments are reported taking the tuning shift into account. A back-calibration was performed to verify the shift in peak-centering, which typically resulted in an upwards shift by $5 \mathrm{amu}$ in the range of 200-220 amu during positive mode operation. To distinguish between ions monitored in the different modes of the instrument a $(+)$ or $(-)$ is indicated in front of the $\mathrm{m} / \mathrm{z}$ monitored for ions monitored in positive and negative mode operation, respectively.

An Aerodyne high-resolution time-of-flight aerosol mass spectrometer (DeCarlo et al., 2006), hereafter referred to as the AMS, was operated at $1 \mathrm{~min}$ resolution, switching between the lower resolution (up to $\sim 2100$ at $\mathrm{m} / \mathrm{z} 200$ ), higher sensitivity "V-mode", and the high-resolution (up to $\sim 4300$ at $\mathrm{m} / \mathrm{z}$ 200), lower sensitivity "W-mode". Data analysis and calibrations were performed according to procedures previously described (Allan et al., 2004; Aiken et al., 2007, 2008; Canagaratna et al., 2007). HR-ToF-AMS data were processed with Squirrel, the ToF-AMS Unit Resolution Analysis Toolkit and PIKA (Peak Integration by Key Analysis, DeCarlo et al., 2006), the high-resolution analysis software tool (http://cires.colorado.edu/jimenez-group/ ToFAMSResources/ToFSoftware/index.html) in Igor Pro Version 6.22A (Wavemetrics, Lake Oswego, OR). At the beginning of each experiment, an AMS sample was taken with a particle filter in-line to the chamber sample line to make corrections for air interferences (Allan et al., 2004). The adjustments to the fragmentation table proposed by Aiken et al. (2008) for organic mass at $\mathrm{m} / \mathrm{z}, 18$ and $\mathrm{m} / \mathrm{z}, 28$ were included. Elemental ratios were calculated using the technique outlined by Aiken et al. $(2007,2008)$. The $\mathrm{C}_{2} \mathrm{H}_{4}^{+}$ion at $\mathrm{m} / \mathrm{z} 28$ was 
Table 2. Experimental conditions.

\begin{tabular}{|c|c|c|c|c|c|c|c|c|c|}
\hline Exp. & Organic & $\begin{array}{c}\text { Duration of } \\
\text { photooxidation }(\mathrm{h})\end{array}$ & $\begin{array}{l}\text { Initial HC } \\
\left(\mathrm{ppb}_{\mathrm{v}}\right)\end{array}$ & $\begin{array}{l}{[\mathrm{NO}]_{0}} \\
\left(\mathrm{ppb}_{\mathrm{v}}\right)\end{array}$ & $\begin{array}{r}{\left[\mathrm{NO}_{\mathrm{x}}\right]_{0}} \\
\left(\mathrm{ppb}_{\mathrm{v}}\right)\end{array}$ & $\begin{array}{l}{\left[\mathrm{O}_{3}\right]_{0}} \\
\left(\mathrm{ppb}_{\mathrm{v}}\right)\end{array}$ & $\begin{array}{l}\text { Initial Seed Vol. } \\
\mu \mathrm{m}^{3} \mathrm{~cm}^{-3}\end{array}$ & $\begin{array}{l}\Delta \mathrm{HC} \\
\left(\mathrm{ppb}_{\mathrm{v}}\right)\end{array}$ & $\begin{array}{c}\text { Peak Organic }^{\mathrm{a}} \\
\mu \mathrm{g} \mathrm{m}^{-3}\end{array}$ \\
\hline 1 & $n$-dodecane & 18 & 33.0 & $<\mathrm{LDL}^{\mathrm{b}}$ & $<\mathrm{LDL}^{\mathrm{b}}$ & 3.3 & 12.0 & 32.3 & 51.3 \\
\hline 2 & $n$-dodecane & 36 & 34.9 & $<\mathrm{LDL}^{\mathrm{b}}$ & $<\mathrm{LDL}^{\mathrm{b}}$ & 2.6 & 11.4 & 33.6 & 62.8 \\
\hline 3 & 2-methylundecane & 18 & 27.3 & $<\mathrm{LDL}^{\mathrm{b}}$ & $<\mathrm{LDL}^{\mathrm{b}}$ & 4.0 & 16.3 & 22.4 & not available $e^{c}$ \\
\hline 4 & 2-methylundecane & 36 & 28.9 & $<\mathrm{LDL}^{\mathrm{b}}$ & $<\mathrm{LDL}^{\mathrm{b}}$ & 4.2 & 13.6 & 27.6 & 45.6 \\
\hline 5 & hexylcyclohexane & 18 & 16.2 & $<\mathrm{LDL}^{\mathrm{b}}$ & $<\mathrm{LDL}^{\mathrm{b}}$ & 2.4 & 10.5 & 15.2 & 34.8 \\
\hline 6 & hexylcyclohexane & 36 & 14.9 & $<\mathrm{LDL}^{\mathrm{b}}$ & $<\mathrm{LDL}^{\mathrm{b}}$ & 3.8 & 4.2 & 14.4 & 34.4 \\
\hline 7 & cyclododecane & 18 & 10.1 & $<\mathrm{LDL}^{\mathrm{b}}$ & $<\mathrm{LDL}^{\mathrm{b}}$ & 2.0 & 24.4 & 9.2 & $19.5^{d}$ \\
\hline 8 & cyclododecane & 36 & 11.0 & $<\mathrm{LDL}^{\mathrm{b}}$ & $<\mathrm{LDL}^{\mathrm{b}}$ & 3.1 & 14.1 & 10.6 & 30.8 \\
\hline
\end{tabular}

a Not corrected for particle wall loss

b Below lower detection limit $\left(5 \mathrm{ppb}_{\mathrm{v}}\right)$

c AMS not sampling

${ }^{\mathrm{d}}$ Reported for end of experiment, though growth had not peaked.

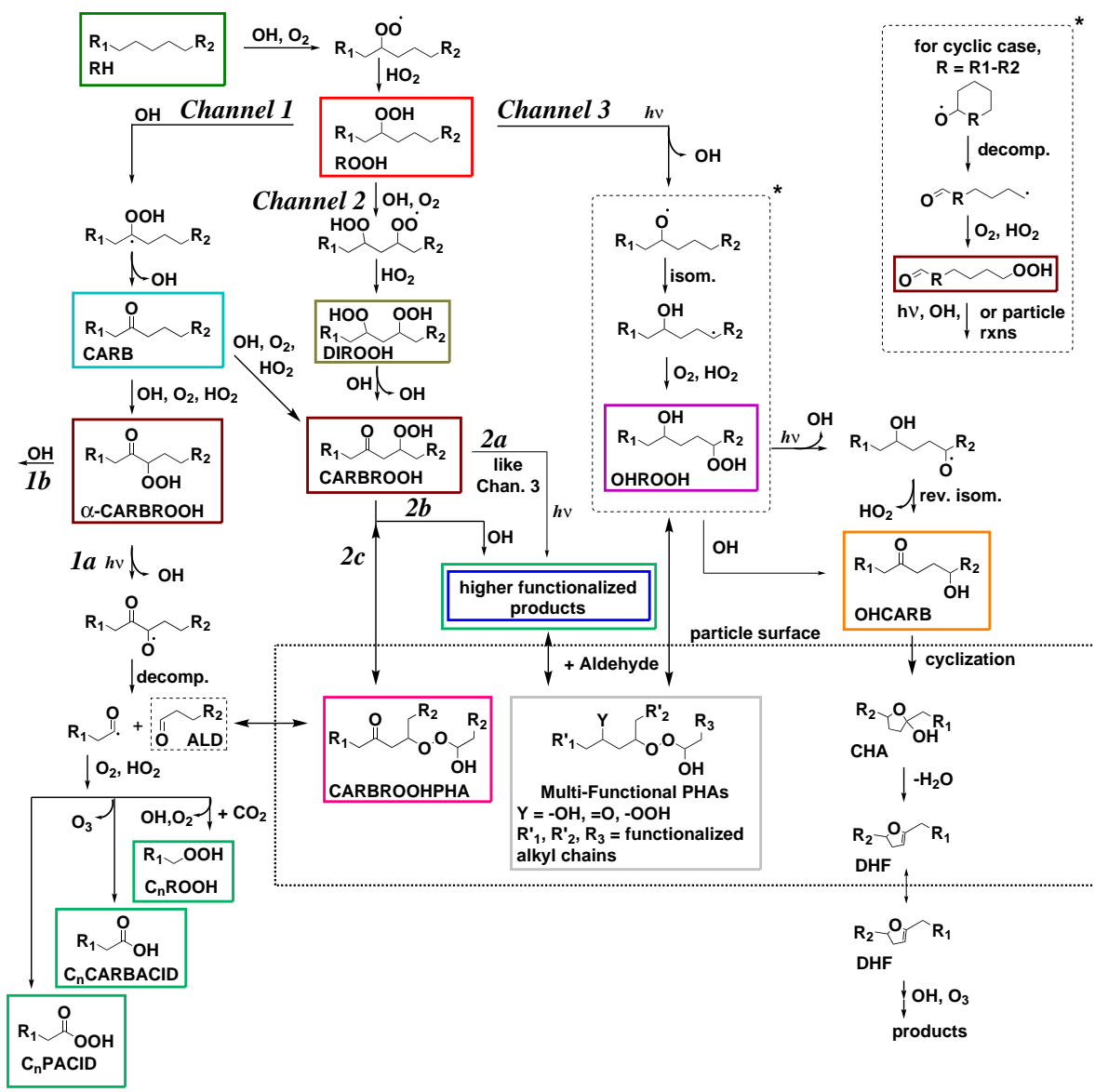

Fig. 1. General mechanism for alkanes under low- $\mathrm{NO}_{\mathrm{x}}$ conditions. $\mathrm{R}_{1}$ and $\mathrm{R}_{2}$ are alkyl groups. Solid boxed compounds indicate proposed structures monitored by the CIMS in the gas-phase and/or the AMS in the particle-phase. Pathway in upper right with asterisk denotes alternative pathway for the cyclic case $\left(\mathrm{R}_{1}\right.$ and $\mathrm{R}_{2}$ are bonded together as $\left.\mathrm{R}\right)$.

not fit in PIKA due to strong interference from $\mathrm{N}_{2}^{+}$and was therefore not included in the elemental ratio calculations.
Photochemical simulations of each system were performed based on that of $n$-dodecane used in Yee et al. (2012) to further define the level of NO. An initial NO 
level of $\leq 1 \mathrm{ppb}_{\mathrm{v}}$ is consistent with $\leq 10 \%$ of reactions of $\mathrm{RO}_{2}$ being due to reaction with $\mathrm{NO}_{\mathrm{x}}$. This NO concentration is also consistent with the trends observed for $\mathrm{NO}_{\mathrm{x}}{ }^{-}$ sensitive species such as the first generation hydroperoxide and the 1,4-hydroxycarbonyl. Multifunctional nitrate species in the CIMS spectra were not significant, supporting that the $\mathrm{RO}_{2}+\mathrm{NO}_{\mathrm{x}}$ channels are not significant in these experiments.

\section{SOA formation chemistry}

\subsection{Chemical mechanism leading to SOA formation}

A proposed general mechanism for the photooxidation of alkanes under low- $\mathrm{NO}_{\mathrm{x}}$ conditions (i.e., $\mathrm{RO}_{2}$ reacts exclusively with $\mathrm{HO}_{2}$ ) is presented in Fig. 1. This scheme is based on the $n$-dodecane photooxidation mechanism developed in Yee et al. (2012) generalized to the $C_{12}$ structures studied here. $R_{1}$ and $R_{2}$ represent alkyl groups. In the case of $n$ dodecane, $\mathrm{R}_{1}$ and $\mathrm{R}_{2}$ are any straight-chain alkyl groups that sum to $\mathrm{C}_{7} \mathrm{H}_{16}$. For 2-methylundecane, $\mathrm{R}_{1}$ and $\mathrm{R}_{2}$ are also alkyl groups that make up $\mathrm{C}_{7} \mathrm{H}_{16}$, though one side contains a methyl branch at the number 2 carbon atom. For hexylcyclohexane, $\mathrm{R}_{1}$ is $\mathrm{C}_{6} \mathrm{H}_{5}$ and $\mathrm{R}_{2}$ is $\mathrm{CH}_{3}$. While the sites of oxidation are shown in the mechanism to occur between $\mathrm{R}_{1}$ and $\mathrm{R}_{2}$, oxidation can also occur on the $\mathrm{R}_{1}$ and $\mathrm{R}_{2}$ groups including the $\mathrm{C}_{6} \mathrm{H}_{5}$ ring in hexylcyclohexane. In the case of cyclododecane, $\mathrm{R}_{1}$ and $\mathrm{R}_{2}$ are bonded together, indicated as $\mathrm{R}$ in the sidebar denoted by an asterisk. Structures in a solid box indicate one isomer of a product identified by the CIMS in the gas phase or the AMS in the particle phase. Colors of boxes containing compounds are consistent with those used when comparing trends of species in later plots within a compound system. Product names within the boxes will continue to be referenced in the following discussion, tables of identified products, and figures.

Photooxidation begins with $\mathrm{H}$-abstraction by $\mathrm{OH}$ from the parent alkane $(\mathrm{RH})$ to form an alkylperoxy radical $\left(\mathrm{RO}_{2}\right)$. Under the experimental conditions, the fate of the $\mathrm{RO}_{2}$ radical is dominated by reaction with $\mathrm{HO}_{2}$ radical $(\geq 90 \%)$ to form the 1st-generation hydroperoxide (ROOH). This calculation is based on analogous photochemical simulations as presented for $n$-dodecane in Yee et al. (2012), which also demonstrate that the time constant by which $\mathrm{RO}_{2}+\mathrm{RO}_{2}$ reactions become significant is greater than 9 days, not relevant for the current experiments. The hydroperoxide $(\mathrm{ROOH})$ can then undergo reaction with $\mathrm{OH}$ (channels 1 and 2) or photolysis (channel 3). Along channel 1, a 2ndgeneration carbonyl (CARB) is formed, followed by continued oxidation to form a 3rd-generation carbonyl hydroperoxide (CARBROOH). This CARBROOH can also be generated via channel 2 , in which $\mathrm{ROOH}$ undergoes reaction with $\mathrm{OH}$ to generate a dihydroperoxide (DIROOH). In the case of channel 1 where the carbonyl hydroperoxide forms such that the functional groups are on adjacent carbons $(\alpha-$
CARBROOH), photolysis of the hydroperoxy group (channel 1a) results in formation of an aldehyde (ALD) and several $<\mathrm{C}_{12}$ fragments: peracid $\left(\mathrm{C}_{n} \mathrm{PACID}\right)$, carboxylic acid $\left(\mathrm{C}_{n} \mathrm{CARBACID}\right)$, and hydroperoxides $\left(\mathrm{C}_{n} \mathrm{ROOH}\right)$. The formation of the $\alpha$-CARBROOH is expected to be minor, as several other isomers would result with the hydroperoxy group located at any of several other possible positions along the carbon chain. It could be located beta to the ketone containing carbon, as shown in channel 2 , or at positions greater than 2 methylene carbons away (not explicitly shown).

Along channel 2, the carbonyl hydroperoxide (CAR$\mathrm{BROOH}$ ) can undergo photolysis (channel 2a) analogous to the reactions outlined in channel 3 , or react with $\mathrm{OH}$ (channel $2 b$ ). Channels $2 a$ and $2 b$ both lead to higher functionalized products. There is potential for tri-functionalized compounds (not shown) to form, a hydroxy carbonyl hydroperoxide (OHCARBROOH) to be formed along channel $2 \mathrm{a}$ and a dicarbonyl hydroperoxide (DICARBROOH) along channel 2b. Additional oxidation (not shown) can lead to a tricarbonyl hydroperoxide (TRICARBROOH) and hydroxy dicarbonyl hydroperoxide (OHDICARBROOH). The carbonyl hydroperoxide (CARBROOH) has a pure liquid vapor pressure ranging from $6.1 \times 10^{-9}$ to $6.6 \times 10^{-8} \mathrm{~atm}$ depending on structure, as estimated using the EVAPORATION method (Compernolle et al., 2011). This intermediate volatile/semivolatile organic is one of the first products that can partition to the particle phase, channel $2 \mathrm{c}$.

In channel 3, photolysis of the 1st-generation hydroperoxide produces an alkoxy radical $\mathrm{RO}$. The $\mathrm{C}_{12}$ alkoxy radical will undergo 1,4-isomerization according to well-established mechanisms (Atkinson, 1997; Lim and Ziemann, 2005, 2009a, b). This results in the formation of a 1,4-hydroxy hydroperoxide $(\mathrm{OHROOH})$, which has sufficiently low volatility to partition into the particle phase or undergo reaction with $\mathrm{OH}$ or photolyze. Reaction with $\mathrm{OH}$ can result in the formation of a carbonyl hydroperoxide (pathway not shown) or a hydroxy carbonyl. The particular carbonyl hydroperoxide and hydroxy carbonyl generated would be different isomers of the generalized CARBROOH and OHCARB shown in the mechanism. The 1,4-hydroxy carbonyl is known to undergo cyclization under an acid-catalyzed process on the particle surface to generate a cyclic hemiacetal (CHA) and dehydrate to form a dihydrofuran (DHF), which can then return to the gas phase to become further oxidized (Aschmann et al., 2003; Lim and Ziemann, 2009c).

In the case of cyclododecane where the ring strain is high enough (Benson, 1976; Lim and Ziemann, 2009a), the alkoxy radical can decompose to generate an aldehydic alkyl radical and a hydroperoxy aldehyde according to the asterisked scheme to the right-hand side (see Fig. 1). Though a $\mathrm{C}_{6}$ ring is not considered to have ring strain (Benson, 1976; Lim and Ziemann, 2009a), hexylcyclohexane may also undergo ring opening in an analogous process, depending on the extent and position of functionalization on the ring and its alkyl chain during continued oxidation. By structure activity 


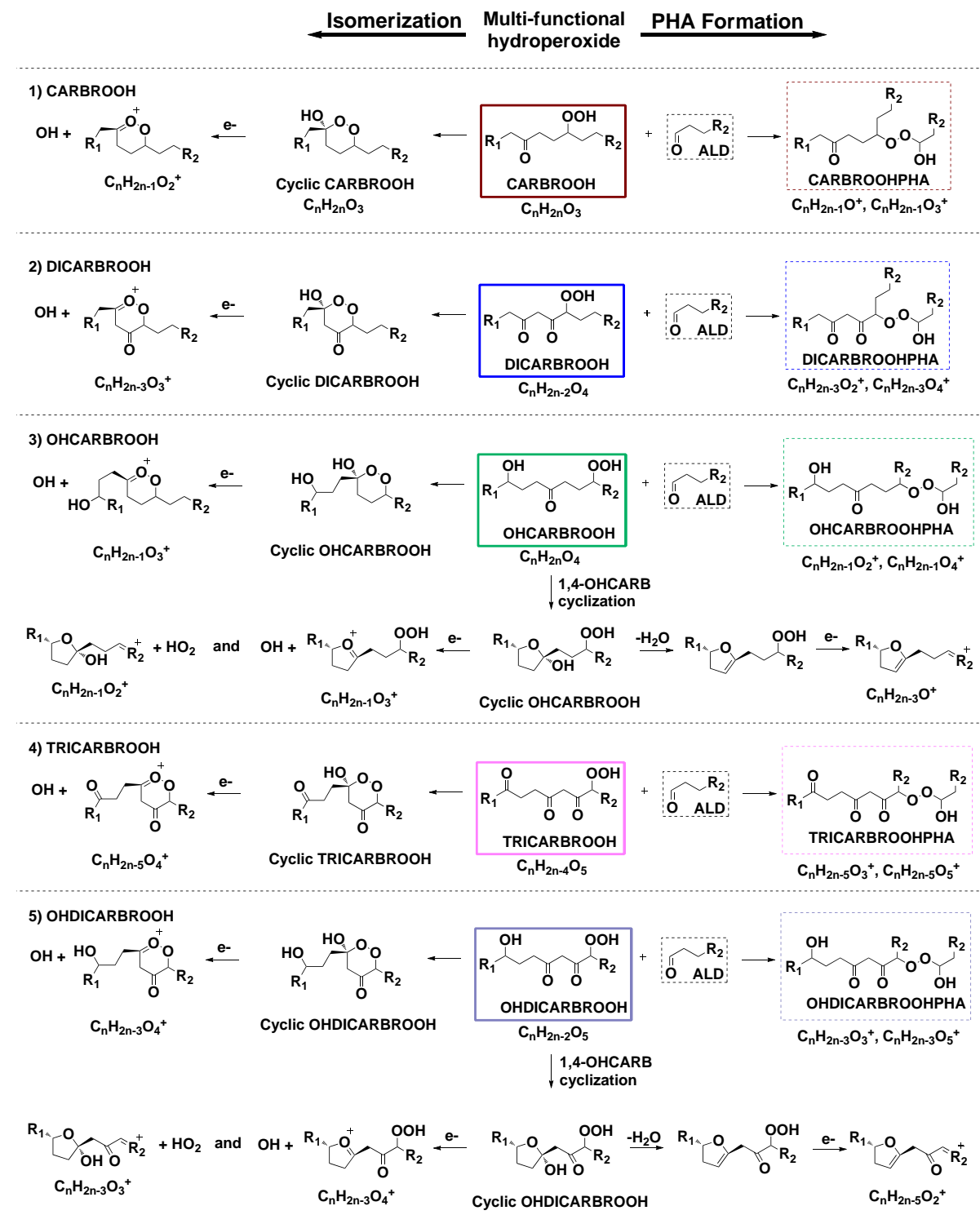

Fig. 2. General mechanism for particle-phase chemistry involving PHA formation (right-hand side) and potential isomerization (left-hand side) from higher functionalized products (solid boxed) formed along channel 2 in Fig. $1 . \mathrm{R}_{1}$ and $\mathrm{R}_{2}$ are alkyl groups. One isomer is shown. Dashed boxed compounds indicate PHA structures for which AMS ion tracers exist. General chemical and ion formulae for multifunctional hydroperoxides and proposed PHA and isomerization products are shown, where $n=12$. Analogous products for hexylcyclohexane and cyclododecane would have an additional degree of unsaturation.

estimations (Kwok and Atkinson, 1995), initial H-abstraction by $\mathrm{OH}$ should primarily take place at the secondary carbons over the branching point in an approximate $80 \%$ to $20 \%$ ratio. Continued oxidation will tend to favor these secondary carbon sites over the branching point, though eventually fragmentation may be induced.

Several multifunctional hydroperoxides can potentially react with the aldehydes generated in channel 1a to form peroxyhemiacetals. The carbonyl hydroperoxide PHA (CARBROOHPHA) is explicitly shown in the mechanisms (Figs. 1 and 2 , scheme 1 ), and was proposed as a key component of the initial SOA growth in the case of $n$-dodecane (Yee et al., 2012). Multifunctional PHAs are represented generally in Fig. 1, where $\mathrm{Y}$ is any functional group (-hydroxyl, carbonyl, -hydroperoxy). The more explicit representation of expected higher functionalized products along channel 2 and their potential to form PHAs are represented along the righthand side of Fig. 2. One isomer is shown with the expected functionalization. PHA formation from DIROOH (Fig. 1, channel 2) and OHROOH (Fig. 1, channel 3) is not explicitly shown since these tracer ions are relatively small signals compared to those of other multifunctional hydroperoxides 


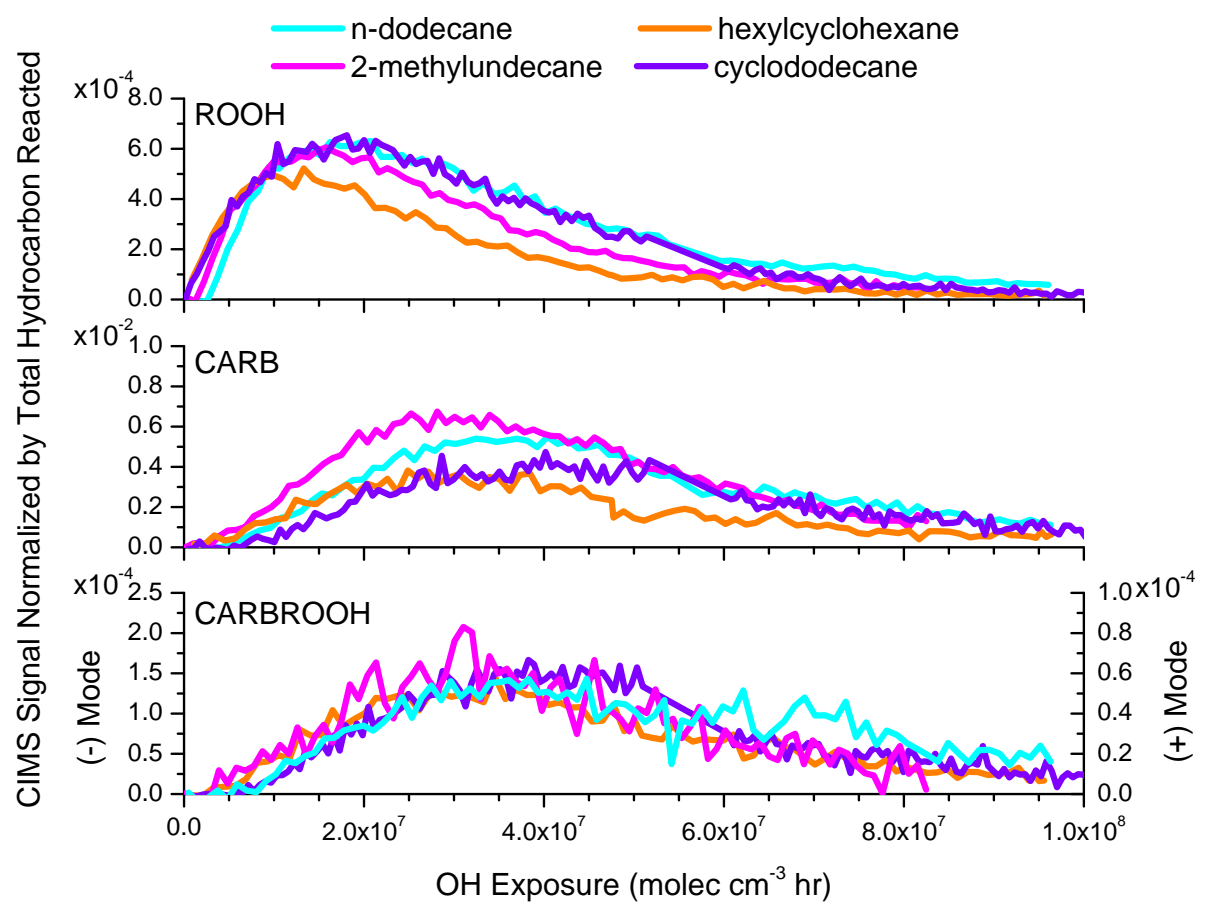

Fig. 3. Gas-phase trends of major species formed in the first three generations of photooxidation. Top panel: first-generation hydroperoxide $(\mathrm{ROOH})$. Middle panel: second-generation carbonyl (CARB). Bottom panel: third-generation carbonyl hydroperoxide (CARBROOH). Note that the CARBROOH was monitored in positive mode for $n$-dodecane and 2-methylundecane (the right side axis) and in negative mode for hexylcyclohexane and cyclododecane (the left side axis).

in the AMS. Of note is the potential to generate a 2ndgeneration $\mathrm{C}_{12}$ hydroperoxy aldehyde in the case of cyclododecane, which is a likely candidate for participating in peroxyhemiacetal formation. Under channels 1 and 2, the CAR$\mathrm{BROOH}$ is a 3rd-generation product, though continued reaction with $\mathrm{OH}$ in these channels may compete with one generation of $\mathrm{OH}$ reaction and photolysis to form the hydroperoxy aldehyde.

\subsection{Gas- and particle-phase product identification using CIMS and AMS}

Ions monitored by the CIMS and the AMS and their proposed compound assignments by system are presented in Tables 3-7. Note that because hexylcyclohexane and cyclododecane differ by one degree of unsaturation from that of 2-methylundecane and $n$-dodecane, many of the ions monitored across sytems for analogous products differ by just $2 \mathrm{amu}$.

\subsubsection{Gas-phase mechanism comparison}

Comparisons of the several analogous gas-phase species across systems help elucidate the chemical development by structure. Associated CIMS signals are normalized by the total reacted hydrocarbon to account for differences in initial hydrocarbon loading and represented along an $\mathrm{OH}$ exposure
Table 3. Selected ions monitored by the CIMS for $n$-dodecane and 2-methylundecane.

\begin{tabular}{lccc}
\hline Mode & Observed $m / z$ & Chemical Formula & Assignment \\
\hline$(-)$ & 287 & $\mathrm{C}_{12} \mathrm{H}_{26} \mathrm{O}_{2}$ & ROOH \\
$(+)$ & 223 & $\mathrm{C}_{12} \mathrm{H}_{24} \mathrm{O}$ & CARB \\
$(+)$ & 204 & $\mathrm{C}_{12} \mathrm{H}_{24} \mathrm{O}_{3}$ & CARBROOH \\
$(-)$ & 285 & $\mathrm{C}_{12} \mathrm{H}_{24} \mathrm{O}_{2}$ & OHCARB \\
$(-)$ & $135 / 201$ & $\mathrm{C}_{6} \mathrm{H}_{12} \mathrm{O}_{2}$ & C6CARBACID \\
\hline
\end{tabular}

Table 4. Selected ions monitored by the CIMS for hexylcyclohexane and cyclododecane.

\begin{tabular}{lccc}
\hline Mode & Observed $m / z$ & Chemical Formula & Assignment \\
\hline$(-)$ & 285 & $\mathrm{C}_{12} \mathrm{H}_{24} \mathrm{O}_{2}$ & ROOH \\
$(+)$ & 221 & $\mathrm{C}_{12} \mathrm{H}_{22} \mathrm{O}$ & CARB \\
$(-)$ & 299 & $\mathrm{C}_{12} \mathrm{H}_{22} \mathrm{O}_{3}$ & CARBROOH \\
$(-)$ & 283 & $\mathrm{C}_{12} \mathrm{H}_{22} \mathrm{O}_{2}$ & OHCARB \\
$(-)$ & $135 / 201$ & $\mathrm{C}_{6} \mathrm{H}_{12} \mathrm{O}_{2}$ & C6CARBACID \\
\hline
\end{tabular}

timescale for comparison of the different systems (Fig. 3). While there are slight differences in magnitude of the curves presented, gas-phase yields are not inferred from these figures as slight variations in the CIMS sensitivity based on structure may account for this effect. Time profiles of total 
Table 5. Selected ions monitored by the AMS in the $n$-dodecane and 2-methylundecane systems.

\begin{tabular}{lcc}
\hline Observed $m / z$ & Exact mass ion formula & Proposed assignment \\
\hline 183 & $\mathrm{C}_{12} \mathrm{H}_{23} \mathrm{O}^{+}$ & CARBROOH + CARBROOH PHA \\
215 & $\mathrm{C}_{12} \mathrm{H}_{23} \mathrm{O}_{3}^{+}$ & CARBROOH PHA \\
\hline 185 & $\mathrm{C}_{12} \mathrm{H}_{25} \mathrm{O}^{+}$ & OHROOH + OHROOH PHA \\
217 & $\mathrm{C}_{12} \mathrm{H}_{25} \mathrm{O}_{3}^{+}$ & OHROOH PHA \\
\hline 197 & $\mathrm{C}_{12} \mathrm{H}_{21} \mathrm{O}_{2}^{+}$ & DICARBROOH + DICARBROOH PHA \\
229 & $\mathrm{C}_{12} \mathrm{H}_{21} \mathrm{O}_{4}^{+}$ & DICARBROOH PHA + CYC. OHDICARBROOH \\
\hline 199 & $\mathrm{C}_{12} \mathrm{H}_{23} \mathrm{O}_{2}^{+}$ & OHCARBROOH + OHCARBROOH PHA \\
231 & $\mathrm{C}_{12} \mathrm{H}_{23} \mathrm{O}_{4}^{+}$ & OHCARBROOH PHA \\
\hline 201 & $\mathrm{C}_{12} \mathrm{H}_{25} \mathrm{O}_{2}^{+}$ & DIROOH \\
\hline 211 & $\mathrm{C}_{12} \mathrm{H}_{19} \mathrm{O}_{3}^{+}$ & TRICARBROOH + TRICARBROOH PHA \\
243 & $\mathrm{C}_{12} \mathrm{H}_{19} \mathrm{O}_{5}^{+}$ & TRICARBROOH PHA \\
\hline 213 & $\mathrm{C}_{12} \mathrm{H}_{21} \mathrm{O}_{3}^{+}$ & OHDICARBROOH + OHDICARBROOH PHA \\
245 & $\mathrm{C}_{12} \mathrm{H}_{21} \mathrm{O}_{5}^{+}$ & OHDICARBROOH PHA \\
\hline
\end{tabular}

Table 6. Selected ions monitored by the AMS in the hexylcyclohexane system.

\begin{tabular}{ccc}
\hline Observed $\mathrm{m} / z$ & Exact mass ion formula & Proposed assignment \\
\hline 179 & $\mathrm{C}_{12} \mathrm{H}_{19} \mathrm{O}^{+}$ & OHCARBROOH DHF \\
\hline 181 & $\mathrm{C}_{12} \mathrm{H}_{21} \mathrm{O}^{+}$ & CARBROOH + CARBROOH PHA \\
213 & $\mathrm{C}_{12} \mathrm{H}_{21} \mathrm{O}_{3}^{+}$ & CARBROOH PHA \\
\hline 183 & $\mathrm{C}_{12} \mathrm{H}_{23} \mathrm{O}^{+}$ & OHROOH + OHROOH PHA \\
215 & $\mathrm{C}_{12} \mathrm{H}_{23} \mathrm{O}_{3}^{+}$ & OHROOH PHA \\
\hline 195 & $\mathrm{C}_{12} \mathrm{H}_{19} \mathrm{O}_{2}^{+}$ & DICARBROOH + DICARBROOH PHA \\
227 & $\mathrm{C}_{12} \mathrm{H}_{19} \mathrm{O}_{4}^{+}$ & DICARBROOH PHA + CYC. OHDICARBROOH \\
\hline 197 & $\mathrm{C}_{12} \mathrm{H}_{21} \mathrm{O}_{2}^{+}$ & OHCARBROOH + OHCARBROOH PHA \\
229 & $\mathrm{C}_{12} \mathrm{H}_{21} \mathrm{O}_{4}^{+}$ & OHCARBROOH PHA \\
\hline 199 & $\mathrm{C}_{12} \mathrm{H}_{23} \mathrm{O}_{2}^{+}$ & DIROOH \\
\hline 209 & $\mathrm{C}_{12} \mathrm{H}_{17} \mathrm{O}_{3}^{+}$ & TRICARBROOH + TRICARBROOH PHA \\
\hline 211 & $\mathrm{C}_{12} \mathrm{H}_{19} \mathrm{O}_{3}^{+}$ & OHDICARBROOH + OHDICARBROOH PHA \\
243 & $\mathrm{C}_{12} \mathrm{H}_{19} \mathrm{O}_{5}^{+}$ & OHDICARBROH PHA \\
\hline
\end{tabular}

reacted hydrocarbon and the decay of $\mathrm{H}_{2} \mathrm{O}_{2}$ for each system are presented in the Supplement (Fig. S1).

The $\mathrm{OH}$ exposure in the system is defined as the product of the concentration of $\mathrm{OH}\left(\right.$ molec $\left.\mathrm{cm}^{-3}\right)$ and the hours of irradiation. The $\mathrm{OH}$ concentration is inferred from the parent hydrocarbon decay using the known reaction rate coefficient with $\mathrm{OH}$. The $\mathrm{OH}$ concentration over the course of an experiment is constant $\left(\sim 2 \times 10^{6}\right.$ molec cm $\left.^{-3}\right)$. Total $\mathrm{OH}$ exposure ranges from $\sim 8 \times 10^{7} \mathrm{molec}^{-3} \mathrm{~h}$ to $\sim 1 \times 10^{8}$ molec $\mathrm{cm}^{-3} \mathrm{~h}$ for these experiments.

The 1st-generation hydroperoxides $(\mathrm{ROOH})$ trends across systems are shown in Fig. 3, top panel. Under similar OH ex- posures, the hexylcyclohexane hydroperoxide peaks slightly earlier than those of $n$-dodecane and cyclododecane. This is consistent with a slightly faster reaction rate coefficient for hexylcyclohexane. The 2nd-generation carbonyl (CARB) formation is compared across the systems in Fig. 3, middle panel. The trends are also consistent with faster gas-phase oxidation for hexylcyclohexane.

Most of the intermediate hydroperoxide species are best monitored in negative mode operation of the CIMS, but due to the mass scan range ending at $300 \mathrm{amu}$, alternative ions in positive mode were used to track development of some expected products. Major products such as the carbonyl 
Table 7. Selected ions monitored by the AMS in the cyclododecane system.

\begin{tabular}{lcc}
\hline Observed $m / z$ & Exact mass ion formula & Proposed assignment \\
\hline 181 & $\mathrm{C}_{12} \mathrm{H}_{21} \mathrm{O}^{+}$ & CARBROOH + CARBROOH PHA \\
213 & $\mathrm{C}_{12} \mathrm{H}_{21} \mathrm{O}_{3}^{+}$ & CARBROOH PHA \\
\hline 183 & $\mathrm{C}_{12} \mathrm{H}_{23} \mathrm{O}^{+}$ & OHROOH + OHROOH PHA \\
215 & $\mathrm{C}_{12} \mathrm{H}_{23} \mathrm{O}_{3}^{+}$ & OHROOH PHA \\
\hline 195 & $\mathrm{C}_{12} \mathrm{H}_{19} \mathrm{O}_{2}^{+}$ & DICARBROOH + DICARBROOH PHA \\
227 & $\mathrm{C}_{12} \mathrm{H}_{19} \mathrm{O}_{4}^{+}$ & DICARBROOH PHA \\
\hline 197 & $\mathrm{C}_{12} \mathrm{H}_{21} \mathrm{O}_{2}^{+}$ & OHCARBROOH + OHCARBROOH PHA \\
229 & $\mathrm{C}_{12} \mathrm{H}_{21} \mathrm{O}_{4}^{+}$ & OHCARBROOH PHA \\
\hline 199 & $\mathrm{C}_{12} \mathrm{H}_{23} \mathrm{O}_{2}^{+}$ & DIROOH \\
\hline 207 & $\mathrm{C}_{12} \mathrm{H}_{15} \mathrm{O}_{3}^{+}$ & OH4CARBROOH \\
223 & $\mathrm{C}_{12} \mathrm{H}_{15} \mathrm{O}_{4}^{+}$ & CYC. OH4CARBROOH \\
\hline 209 & $\mathrm{C}_{12} \mathrm{H}_{17} \mathrm{O}_{3}^{+}$ & TRICARBROOH/4CARBROOH Ring Opened \\
225 & $\mathrm{C}_{12} \mathrm{H}_{17} \mathrm{O}_{4}^{+}$ & CYC. TRICARBROOH \\
\hline 211 & $\mathrm{C}_{12} \mathrm{H}_{19} \mathrm{O}_{3}^{+}$ & OHDICARBROOH/TRICARBROOH Ring Opened \\
\hline
\end{tabular}

hydroperoxide (CARBROOH) for the 2-methylundecane and $n$-dodecane systems were monitored at $(+) m / z, 204$ for this reason (Table 3), while for hexylcyclohexane and cyclododecane CARBROOH was monitored at (-) $\mathrm{m} / \mathrm{z}, 299$ (Table 4). Note that signal intensities should not be compared across positive and negative mode operation of the CIMS as the sensitivities differ. The CARBROOH trends in Fig. 3 (bottom panel) show similar trends across systems, though the signals are more noisy as this hydroperoxide is expected to be the first species with sufficiently low volatility to partition into the particle phase.

\subsubsection{Particle-phase composition}

Mass spectra (1-2h averages) from the AMS at the time of initial growth, a period mid-experiment, and at experiment end for each system, along with a difference spectrum from end and initial growth, are presented in Figs. 4-7. The initial growth spectrum is taken at the point where the organic aerosol mass rises above the limit of detection. The limit of detection is defined as 3 standard deviations above the signal during the filter period taken before photooxidation begins. The mid-experiment average spectrum is taken at the point where the suspended organic aerosol is the highest, typically coincident with the peak of one or more AMS ion tracers of interest. The peak in suspended organic aerosol is consistent with the effects of particle wall loss and unlikely due to evaporation as the size distribution remains the same. The end spectrum is the average of the spectra during the last $1-2 \mathrm{~h}$ of photooxidation. The $\mathrm{C}_{\mathrm{x}} \mathrm{H}_{\mathrm{y}} \mathrm{O}_{\mathrm{z}}$ chemical formulas corresponding with the dominant exact masses are labeled in the mass spectra. Unit mass $m / z$ is denoted here for brevity, but the re- ported ion chemical formulas are determined from the exact mass ions.

In the $m / z<100$ amu range, several of the dominant $\mathrm{C}_{\mathrm{x}} \mathrm{H}_{\mathrm{y}}^{+}$ ions are shared across all systems, though there is greater relative contribution of cycloalkyl ions compared to alkyl ions in the case of hexylcyclohexane and cyclododecane. For example, there is greater signal of the ion $\mathrm{C}_{6} \mathrm{H}_{7}^{+}$compared to $\mathrm{C}_{6} \mathrm{H}_{9}^{+}$for these systems compared to those of $n$-dodecane and 2-methylundecane. The highest signal is attributed to the same ions for $n$-dodecane and 2-methylundecane (Figs. 4 and 5 ); however, the fraction is higher for $n$-dodecane than in the 2 -methylundecane case. This observation is consistent with more fragmentation in the 2-methylundecane oxidation, as compared to n-dodecane. 2-methylundecane oxidation also exhibits a higher fraction of $\mathrm{C}_{2} \mathrm{H}_{3} \mathrm{O}^{+}$in the $<100 \mathrm{amu}$ range. $\mathrm{C}_{2} \mathrm{H}_{3} \mathrm{O}^{+}$has been proposed as an ion tracer for non-acid organic oxygenates (Chhabra et al., 2011). This ion also tends to dominate during hexylcyclohexane oxidation (Fig. 6) in the 40-45 amu ion cluster range, though it never dominates in the case of cyclododecane (Fig. 7).

In the cyclododecane system one ion tends to predominate within a cluster of ions. For example, $\mathrm{C}_{4} \mathrm{H}_{7}^{+}$at $\mathrm{m} / z 55 \mathrm{domi}-$ nates during initial aerosol growth (Fig. 7) in the 50-60 amu region, whereas in the $n$-dodecane system, ions at $\mathrm{m} / \mathrm{z} 55$ and $m / z, 57$ are present at similar mass fractions (Fig. 4) . At initial growth, they are reduced ions, whereas at maximum growth, the two ions are more oxidized, and the oxidized ion $\left(\mathrm{C}_{3} \mathrm{H}_{5} \mathrm{O}^{+}\right)$at $m / z 57$ is higher. For cyclododecane, the $m / z 55$ ion also shifts from the reduced ion $\left(\mathrm{C}_{4} \mathrm{H}_{7}^{+}\right)$to the more oxidized ion $\left(\mathrm{C}_{3} \mathrm{H}_{3} \mathrm{O}^{+}\right)$and remains predominant in the 50-60 amu range throughout the oxidation. The fraction of mass at $\mathrm{C}_{3} \mathrm{H}_{3} \mathrm{O}^{+}$at $\mathrm{m} / z, 55$ is also high for the entire 


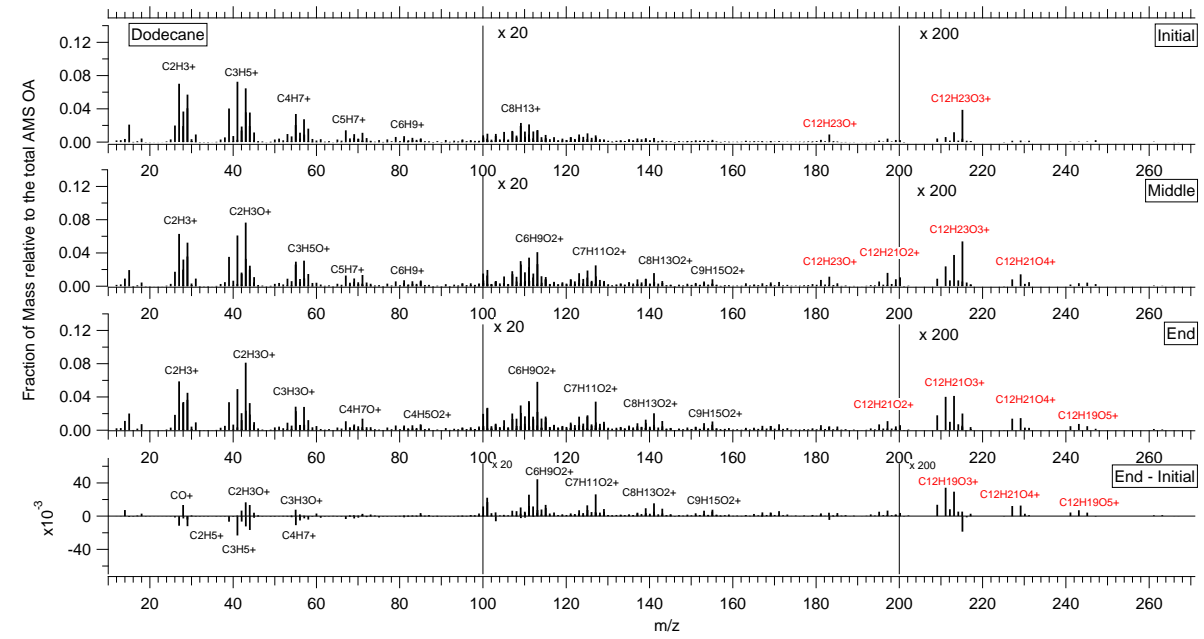

Fig. 4. High-resolution mass spectrum of SOA formed from $n$-dodecane at initial organic growth, mid-experiment, and end of experiment. The difference spectrum is also shown. $\mathrm{m} / \mathrm{z}, 101-200$ are multiplied by 20 , and $m / z, 201-300$ are multiplied by 200 for visual clarity. Ions with high signal are labeled. Ion labels in red correspond with proposed ion assignments in Table 5.

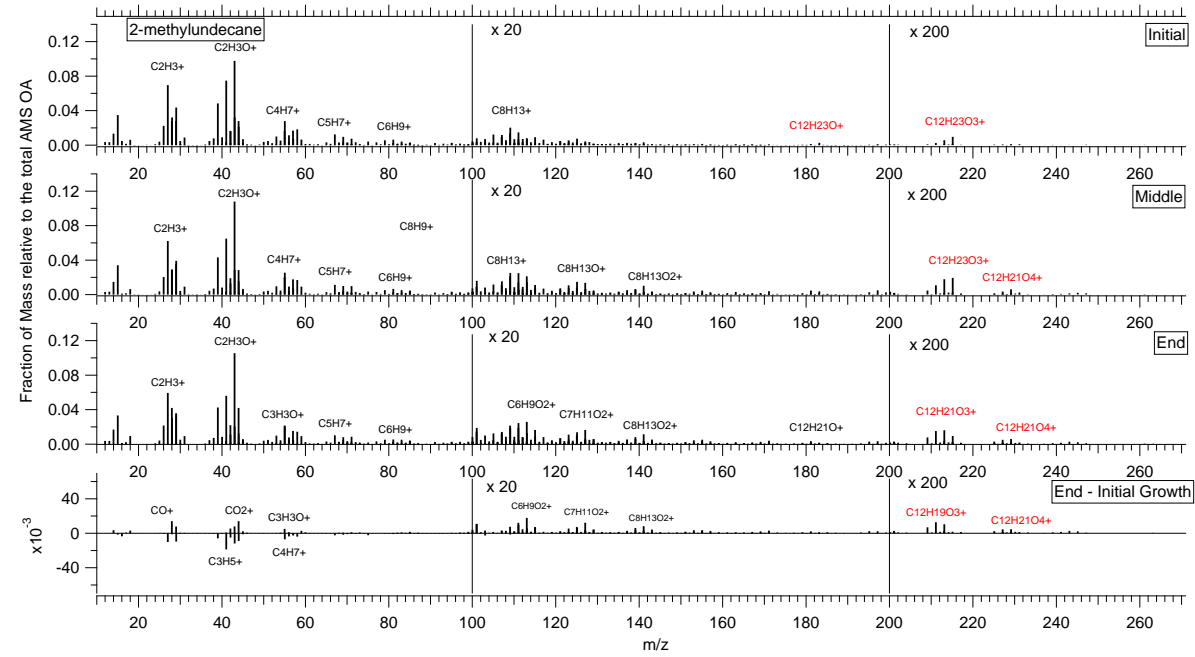

Fig. 5. High-resolution mass spectrum of SOA formed from 2-methylundecane at initial organic growth, mid-experiment, and end of experiment. The difference spectrum is also shown. $\mathrm{m} / \mathrm{z}, 101-200$ are multiplied by 20 , and $\mathrm{m} / \mathrm{z}, 201-300$ are multiplied by 200 for visual clarity. Ions with high signal are labeled. Ion labels in red correspond with proposed ion assignments in Table 5.

duration of the hexylcyclohexane oxidation, whereas in the other systems, the reduced ion $\left(\mathrm{C}_{4} \mathrm{H}_{7}^{+}\right)$at $m / z 55$ is high, and then $\mathrm{C}_{3} \mathrm{H}_{3} \mathrm{O}^{+}$grows in.

The mass spectrum from the hexylcyclohexane system (Fig. 6) between $\mathrm{m} / \mathrm{z}, 100$ and $200 \mathrm{amu}$ is less discretely structured as compared to the other compounds (Figs. 4, 5, 7). Since hexylcyclohexane exhibits alkyl, cyclic, and branched features in its structure, this may be interpreted as a unique hybrid of chemical features in the aerosol spectrum.

Overall, the difference spectra in the $m / z 100-300$ amu region are all positive, indicating the incorporation of higher molecular weight species. The only negative differences in signal are in the $\mathrm{m} / z<100$ range and are the result of alkyl ion fragments decreasing in AMS signals from the particle phase. Several ions in the $>150 \mathrm{amu}$ range have been proposed as tracers for particle-phase chemistry (Yee et al., 2012; Craven et al., 2012), as, though low in signal, they retain more molecular information than lower mass ions that are only small fragments of the original molecule. The chemical processes by which these $>150 \mathrm{amu}$ ions are generated may be analogous across all systems, as the structures of the spectra in this range are generally the same. That is, the prominent ions in hexylcyclohexane correspond to the prominent ions in the $n$-dodecane and 2-methylundecane cases, but tend to have one additional degree of unsaturation. This is consistent with the difference in degrees of 


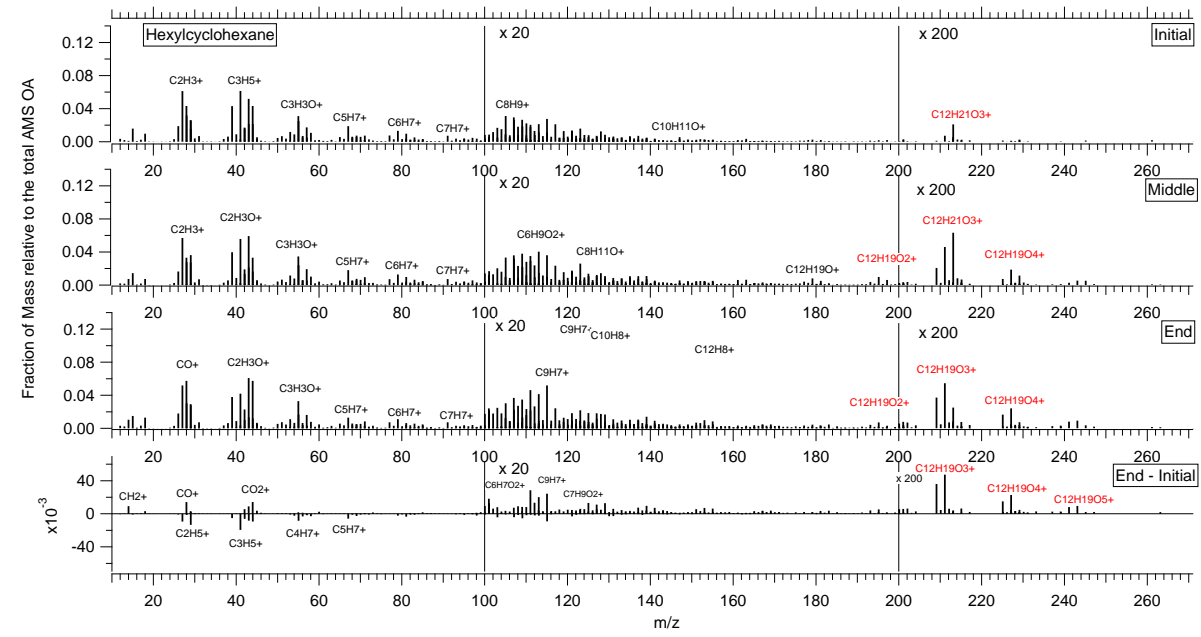

Fig. 6. High-resolution mass spectrum of SOA formed from hexylcyclohexane at initial organic growth, mid-experiment, and end of experiment. The difference spectrum is also shown. $\mathrm{m} / \mathrm{z}, 101-200$ are multiplied by 20 , and $\mathrm{m} / \mathrm{z}, 201-300$ are multiplied by 200 for visual clarity. Ions with high signal are labeled. Ion labels in red correspond with proposed ion assignments in Table 6.

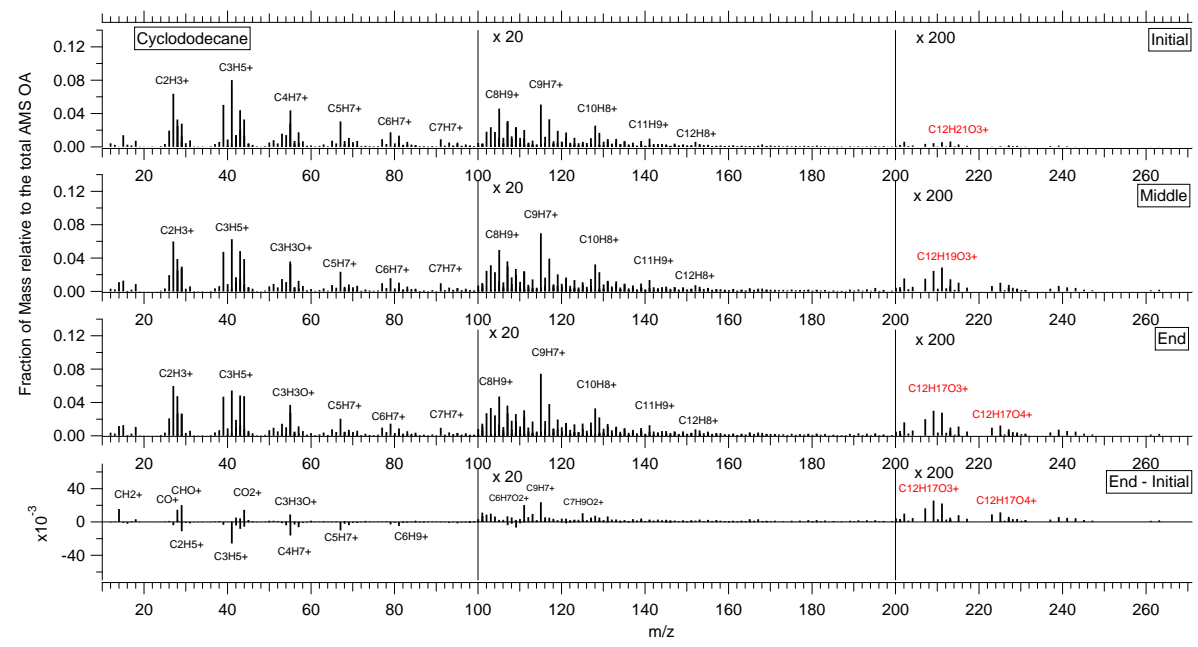

Fig. 7. High-resolution mass spectrum of SOA formed from cyclododecane at initial organic growth, mid-experiment, and end of experiment. The difference spectrum is also shown. $\mathrm{m} / \mathrm{z}, 101-200$ are multiplied by 20 , and $\mathrm{m} / \mathrm{z}, 201-300$ are multiplied by 200 for visual clarity. Ions with high signal are labeled. Ion labels in red correspond with proposed ion assignments in Table 7.

unsaturation between the parent compounds. However, the cyclododecane peaks in this high amu region tend to be two degrees of unsaturation lower than those of $n$-dodecane. This could indicate chemical processing that results in more carbonyl group formation for the case of cyclododecane. This type of functionalization is relevant for cyclododecane along channel 3 in the gas-phase mechanism (Fig. 1), as cyclododecane can ring-open early on, generating an aldehyde. This also means that cyclododecane can form a lower vapor pressure $\mathrm{C}_{12}$ aldehyde that can participate in particlephase reactions as discussed in Lim and Ziemann (2009a, b), whereas other systems form a $<\mathrm{C}_{12}$ aldehyde along channel 1a (Fig. 1).

\subsubsection{Indicators of particle-phase chemistry: peroxy- hemiacetal (PHA) formation}

Yee et al. (2012) and Craven et al. (2012) proposed that several ion tracers in the $\mathrm{m} / \mathrm{z}>150 \mathrm{amu}$ region differing by $32 \mathrm{amu}$ could be used to track a variety of potential peroxyhemiacetals (PHAs) formed in the particle phase. Craven et al. (2012) established that general hydroperoxides $(\mathrm{ROOH})$ could be monitored in the AMS at ions consistent with an $\mathrm{m} / z$ [M-33] $]^{+}$, where $\mathbf{M}$ is the molecular weight of the hydroperoxide. This ion will be hereafter referred to as $\mathrm{R}^{+}$. However, the distinct pattern of similarly trending $\mathrm{R}^{+}$ions and those at $\mathrm{m} / \mathrm{z}, 32 \mathrm{amu}$ higher suggests that this mass difference may result from the peroxide $\mathrm{O}-\mathrm{O}$ bond 
of a peroxyhemiacetal. We refer to this ion as $\mathrm{ROO}^{+}$for the following discussions. We note that because the typical vaporizer temperature in the AMS is operated at $600^{\circ} \mathrm{C}$, as employed in these experiments, the signals from these $m / z>150 \mathrm{amu} \mathrm{R}^{+}$and $\mathrm{ROO}^{+}$ions are small. After running the experiments presented here, Craven et al. (2012) explored the effect of lowering the vaporizer temperature for the case of $\mathrm{C}_{18}$ hydroperoxide in the particle phase and found that greater signal from the hydroperoxide ion tracer could be achieved by doing so. This suggests that future studies exploring hydroperoxide and peroxides in the particle phase may benefit from modification of standard AMS operation. While small in signal for the current experiments, these ions are still crucial indicators of the particle-phase chemistry. These ions are listed in tables of ions monitored in the AMS along with their proposed product assignments (Tables 5-7). Since these initial studies, another $n$-dodecane experiment (Shiraiwa et al., 2013) involved intentional injection of tridecanal in the dark after an initial period of dodecane photooxidation and SOA formation to induce peroxyhemiacetal formation. Upon tridecanal injection, a corresponding decrease in signal of several hyderoperoxide species occurred in the gas phase (as monitored by the CIMS) accompanied by a corresponding increase in the 32 amu difference ion pairs in the AMS, consistent with the proposed attribution to particlephase chemistry involving peroxyhemiacetal formation.

The formation of fragments along channel 1a, specifically carboxylic acids tracked by the CIMS, is the key proxy for the presence of aldehyde in the system (since the aldehyde is not directly measured). The presence of gas-phase acid indicates that aldehyde is present in the system, and that peroxyhemiacetal formation may commence, as observed in Yee et al. (2012) for $n$-dodecane. Hence, a key comparison of the gas- and particle-phase measurements includes the time trend comparison between gas-phase acid production and particle-phase ion markers for PHA formation. In each system, the CARBROOH PHA ions grow in the particle phase when gas-phase aldehyde froms, as proxied by a measured co-product, $\mathrm{C}_{6}$ carboxylic acid (C6CARBACID), in Fig. 8. The initial growth of organic aerosol in each of these systems is also characterized by the respective CARBROOH and CARBROOH PHA tracer ions in the AMS mass spectra. In Figs. 4 and 5, $\mathrm{C}_{12} \mathrm{H}_{23} \mathrm{O}^{+}$at $m / z, 183$ and $\mathrm{C}_{12} \mathrm{H}_{23} \mathrm{O}_{3}^{+}$at $m / z, 215$ are the dominant ions at initial growth of $n$-dodecane and 2-methylundecane SOA. For hexylcyclohexane (Fig. 6) and cyclododecane (Fig. 7), the ion at $\mathrm{C}_{12} \mathrm{H}_{21} \mathrm{O}_{3}^{+}$at $\mathrm{m} / \mathrm{z} 213$ is characteristic of initial growth. Note that there are different right-hand axes and scales for the $\mathrm{R}^{+}$and $\mathrm{ROO}^{+}$ion tracers in Fig. 8.

\subsubsection{Effect of structure on PHA formation}

Common for all four systems, three ions that enter the particle phase early on (within $2 \times 10^{7}$ molec $\mathrm{cm}^{-3} \mathrm{~h} \mathrm{OH}$ exposure) are attributed to their respective CARBROOH,
OHCARBROOH, and DICARBROOH. While the $\mathrm{R}^{+}$ions can come from both the hydroperoxide itself and its derived $\mathrm{PHA}$, the $\mathrm{ROO}^{+}$ion is considered to arise mostly from PHA. To understand the effect of structure on PHA formation, time trends of the fraction of the organic aerosol attributed to $\mathrm{ROO}^{+}$PHA tracer ions can be compared across parent structures. These analyses assume that the ionization probability and fragmentation pattern in the AMS are relatively consistent for PHAs of analogous functionality. That is, the CARBROOH PHA ionization probability is similar across the four $\mathrm{C}_{12}$ alkanes studied. Also, this currently assumes that there is only one hydroperoxide and its PHA (regardless of the aldehyde variety) contributing to the $\mathrm{ROO}^{+}$.

Figure 9 shows that the relative fraction of organic aerosol attributed to the CARBROOH PHA is approximately similar for $n$-dodecane and hexylcyclohexane, followed by 2methylundecane and cyclododecane (top panel). For the DICARBROOH PHA (middle panel) and OHCARBROOH PHA (bottom panel), a greater fraction of the organic aerosol is attributed to PHAs in hexylcyclohexane SOA, followed by $n$-dodecane. Smaller contributions are made for the PHAs from 2-methylundecane and cyclododecane.

Hexylcyclohexane may seem like an outlier since the contribution of PHA ions generally decreases in the order of branching or cyclic character (i.e., $n$-dodecane $>2$ methylundecane $>$ cyclododecane), though it is notably higher than or on the same order of $n$-dodecane. This may be a result of hexylcyclohexane chemistry having the unique mix of many features typically individualized to the other systems. That is, while hexylcyclohexane is branched like 2methylundecane, even if C-C scission is favored at the branch point, the presence of the cyclohexane ring means that gasphase fragmentation can still result in preservation of the $C_{12}$ backbone, unlike 2-methylundecane. This means certain aspects of hexylcyclohexane's chemistry will be akin to that of n-dodecane, supporting continued functionalization and higher MW species. While hexylcyclohexane is also cyclic in nature like cyclododecane, the hexyl-chain may still afford it many sites of reaction without the potential of disrupting the stability of the $\mathrm{C}_{6}$ ring. In the case of cyclododecane, any reaction affects a ring-bound carbon, and as such may impact the resulting chemistry.

Generally, the fraction of organic aerosol attributed to the cyclododecane-derived PHAs is lower compared to the other systems, indicating that there may be structural biases in PHA formation. Since PHA formation relies on the intermolecular reaction of two condensing species, aldehyde and a hydroperoxide, it may be that the cyclic structure of cyclododecane hydroperoxide is less apt for this reaction, depending on the hydroperoxy group accessibility on the $\mathrm{C}_{12}$ ring. It may also be possible that there are competing intramolecular reactions of more highly-functionalized hydroperoxides within the $\mathrm{C}_{12}$ ring that are more easily facilitated. There is also trend information in Fig. 8d that shows that the $\mathrm{R}^{+}$and $\mathrm{ROO}^{+}$ions for CARBROOH PHA in 

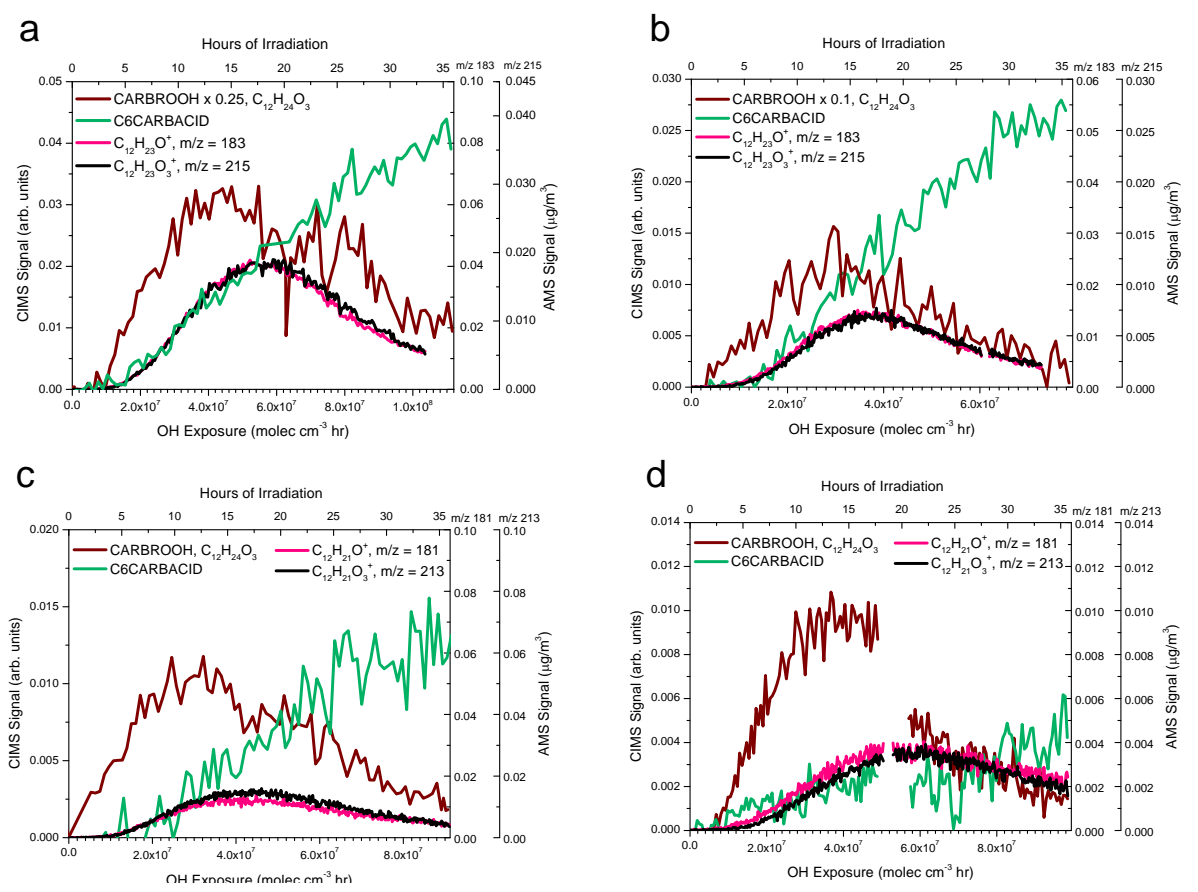

Fig. 8. Gas-phase trends of the generated carbonyl hydroperoxide (CARBROOH) and $\mathrm{C}_{6}$ carboxylic acid (C6CARBACID) as monitored by the CIMS and the CARBROOH and its derived PHA in the particle phase for (a) $n$-dodecane, (b) 2-methylundecane, (c) hexylcyclohexane, and (d) cyclododecane. $\mathrm{CARBROOH}$ and its PHA are tracked by AMS ions $\mathrm{C}_{12} \mathrm{H}_{23} \mathrm{O}^{+}$and $\mathrm{C}_{12} \mathrm{H}_{23} \mathrm{O}_{3}^{+}$for $n$-dodecane and 2-methylundecane, and by $\mathrm{C}_{12} \mathrm{H}_{21} \mathrm{O}^{+}$and $\mathrm{C}_{12} \mathrm{H}_{21} \mathrm{O}_{3}^{+}$for hexylcyclohexane and cylododecane.

cyclododecane do not trend together as tightly as compared to the other systems (Fig. 8a-c). The $\mathrm{ROO}^{+}$ion lags slightly, indicating that PHA formation from the CARBROOH in cyclododecane may not form immediately with the condensation of CARBROOH.

While signal at the $\mathrm{ROO}^{+}$ion for CARBROOH PHA can also potentially be derived from the OHCARBROOH cyclizing, as in Fig. 2, Scheme 3, the tight correlation of the $\mathrm{R}^{+}$ and $\mathrm{ROO}^{+}$ions for $n$-dodecane and 2-methylundecane suggests less of a contribution from competing cyclization. Since the $\mathrm{R}^{+}$ions cannot be derived from the competitive cyclization products, the majority of the signal at the $\mathrm{ROO}^{+}$ion is attributed to the CARBROOH PHA form. For hexylcyclohexane and cyclododecane, however, there is slightly more deviation of the $\mathrm{R}^{+}$and $\mathrm{ROO}^{+}$ion trends. This may suggest that these structures may undergo intramolecular reactions that result in the variety of ions and chemical development discussed in further detail below.

\subsubsection{Indicators of competitive chemistry with peroxy- hemiacetal (PHA) formation}

Here, we present the general particle-phase development in terms of the multifunctional hydroperoxide/PHA $\mathrm{R}^{+}$and PHA $\mathrm{ROO}^{+}$proposed ion tracers for all systems (Fig. 10). In this systematic analysis going from straight-chain to branched to cyclic structures, we find that the presence of cer- tain ions by structure and their trend information informs the need to consider intramolecular reaction as an additional fate of some of the multifunctional hydroperoxides. All ion signals have been normalized by the suspended organic aerosol to account for effects on the ion signal trend due to particle wall loss. This normalization results in large noise at periods $<\mathrm{OH}$ exposure of $2 \times 10^{7}$ molec $\mathrm{cm}^{-3} \mathrm{~h}$, owing to low and noisy ion and organic aerosol signals before this time.

The same tracer ions are present in both the $n$-dodecane and 2-methylundecane systems (Fig. 10a, b). $\mathrm{C}_{12} \mathrm{H}_{19} \mathrm{O}_{3}^{+}$ is of low signal in the 2-methylundecane and $n$-dodecane AMS spectra, though there is a greater contribution from this ion in $n$-dodecane SOA. All of these ions can potentially be explained by multifunctional hydroperoxide compounds that can carry up to four sites of functionalization and three degrees of unsaturation relative to the parent (See PHA schemes in Fig. 2 for proposed multifunctional structures and AMS ions assignments in Table 5). Generally for these acyclic systems, the CARBROOH is initially incorporated, followed by the DICARBROOH $\left(\mathrm{C}_{12} \mathrm{H}_{21} \mathrm{O}_{2}^{+}\right.$at $m / z$ 197) and the OHCARBROOH $\left(\mathrm{C}_{12} \mathrm{H}_{23} \mathrm{O}_{2}^{+}\right.$at $m / z$ 199). Additional chemical processing leads to incorporation of a potential OHDICARBROOH $\left(\mathrm{C}_{12} \mathrm{H}_{21} \mathrm{O}_{3}^{+}\right.$at $\left.\mathrm{m} / \mathrm{z} 213\right)$ and a TRICARBROOH $\left(\mathrm{C}_{12} \mathrm{H}_{19} \mathrm{O}_{3}^{+}\right.$at $\mathrm{m} / z$ 211). The $\mathrm{C}_{12} \mathrm{H}_{19} \mathrm{O}_{5}^{+}$ at $m / z 245$ is possibly the OHDICARBROOH PHA ROO ${ }^{+}$ ion, though the signal at this $\mathrm{m} / \mathrm{z}$ is not sufficiently high to be 


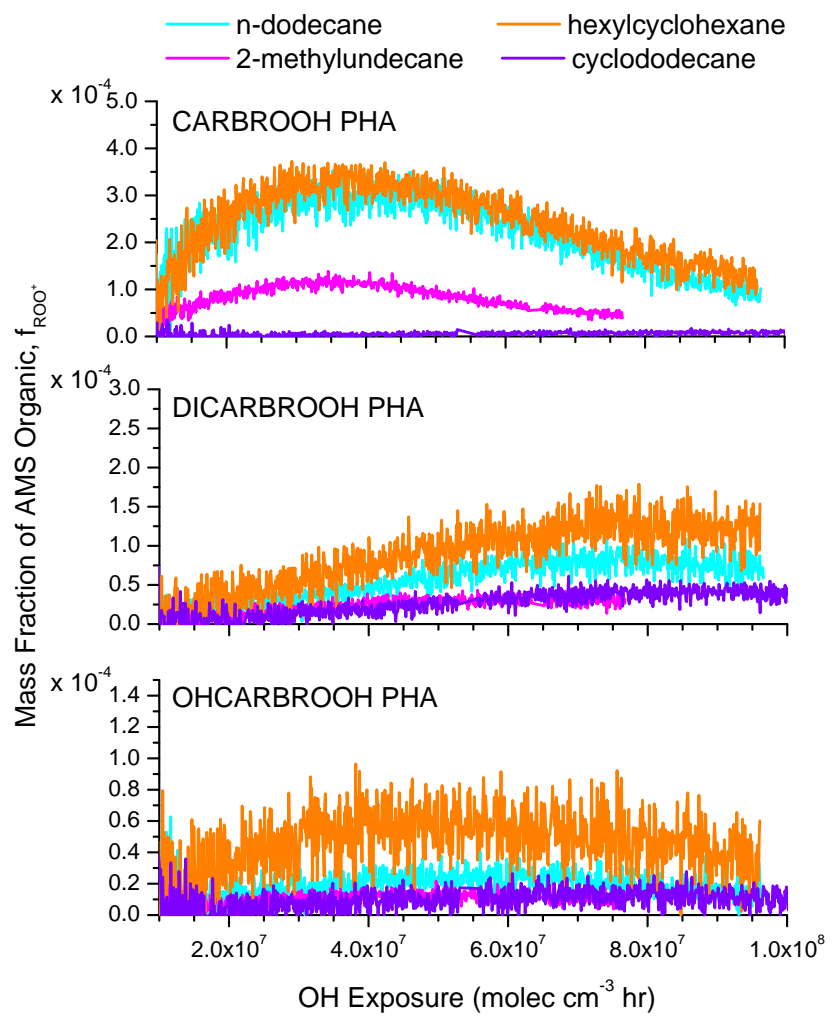

Fig. 9. Fraction of organic attributed to the corresponding $\mathrm{ROO}^{+}$ PHA tracer ion for (top) carbonyl hyderoperoxide PHA (CARBROOH PHA), (middle) dicarbonyl hydroperoxide (DICAR$\mathrm{BROOH}$ ), and (bottom) hydroxycarbonyl hydroperoxide (OHCARBROOH).

plotted on the same scale as the $\mathrm{R}^{+}$ions here. The DIROOH and $\mathrm{OHROOH}$ tracer ions are also not included for this reason, although tracer ions are identified in the mass spectra. Of note is the relatively earlier peaking (in terms of $\mathrm{OH}$ exposure) and lower relative contribution of these ions in the 2-methylundecane system as compared to their analogs in the $n$-dodecane system. This may be a result of fragmentation processes relevant for 2-methylundecane gas-phase oxidation that begin to dominate. The lower relative contribution of $\mathrm{C}_{12} \mathrm{H}_{19} \mathrm{O}_{5}^{+}$for 2-methylundecane SOA as compared to $n$-dodecane SOA is also consistent with less chemical development due to gas-phase fragmentation dominating over functionalization, as well as potentially slower gasphase oxidation since 2-methylundecane has a lower $k_{\mathrm{OH}}$ than that of $n$-dodecane. Though all of these ions for $n$ dodecane and 2-methylundecane can be explained by species involved in PHA formation mechanisms, we find that comparison of these and additional ions in the hexylcyclohexane and cyclododecane system indicate that additional chemistry is present.

For hexylcyclohexane, there is noticeably more simultaneous incorporation in the aerosol phase of such species as the CARBROOH $\left(\mathrm{C}_{12} \mathrm{H}_{21} \mathrm{O}^{+}\right.$at $\left.\mathrm{m} / \mathrm{z}, 181\right)$, DICARBROOH
$\left(\mathrm{C}_{12} \mathrm{H}_{19} \mathrm{O}_{2}^{+}\right.$at $\mathrm{m} / \mathrm{z}$ 195), OHCARBROOH $\left(\mathrm{C}_{12} \mathrm{H}_{21} \mathrm{O}_{2}^{+}\right.$at $\mathrm{m} / \mathrm{z}$ 197), and their respective PHAs (Fig. 10c, Table 6). There is also significant contribution from an ion at $\mathrm{C}_{12} \mathrm{H}_{19} \mathrm{O}^{+}$not explained by the PHA tracer fragmentation pattern. The presence of the $\mathrm{C}_{12} \mathrm{H}_{19} \mathrm{O}^{+}$ion may be a result of forming an analogous hydroperoxy dihydrofuran product (Fig. 2, Scheme 3) via the OHCARBROOH undergoing 1,4 cyclization and dehydration. This ion is unique to hexylcyclohexane SOA (in terms of degrees of unsaturation achieved with little oxygen in the ion formula and prominence of the ion). The proposed reaction is consistent with the hexylcyclohexane structure undergoing another 1,4-cyclization along its $\mathrm{C}_{6}$ branch to form a bicyclic structure (cyclohexyl and cyclic hemiacetal). The cyclic hemiacetal portion of the molecule can then dehydrate to form a dihydrofuran-like structure of higher volatility. This prominent route may therefore limit formation of lower volatility oxidation products during hexylcyclohexane oxidation. The peak of the suspended organic aerosol (Fig. 10c, OH exposure $\sim 5 \times 10^{6}$ molec $\mathrm{cm}^{-3} \mathrm{~h}$ ) does follow the peak of this ion and those of the DICARBROOH, OHCARBROOH, consistent with limitations of the growth. At this point the rate of particle wall loss dominates over the rate of continued growth.

Tracer ions for these products are followed by further chemical processing also leading to the OHDICARBROOH and its PHA $\left(\mathrm{C}_{12} \mathrm{H}_{19} \mathrm{O}_{3}^{+}\right.$at $\mathrm{m} / z$ 211) and the OHDICARBROOH PHA $\left(\mathrm{C}_{12} \mathrm{H}_{19} \mathrm{O}_{5}^{+}\right.$at $\left.\mathrm{m} / z, 243\right)$. The $\mathrm{m} / z, 243$ ion is not shown due to low signal. The ion at $m / z 227 \mathrm{C}_{12} \mathrm{H}_{19} \mathrm{O}_{4}^{+}$ corresponds to the $\mathrm{ROO}^{+}$ion for DICARBROOH PHA, though the time trend does not follow that of the $\mathrm{R}^{+}$ion as closely, and may indicate another species (in combination) being responsible for the signal here. For example, in Fig. 2, Scheme 5, the OHDICARBROOH may isomerize (left reaction) via cyclization between a carbonyl and hydroperoxy group to form this ion as well. It may also undergo 1,4cyclization involving the hydroxy and ketone groups. This presents two potentially competitive fates for the OHDICARBROOH, one to PHA formation (Scheme 5, right reaction) and the other to cyclization (Scheme 5, left and bottom reaction). Cyclization of alkoxy hydroperoxy aldehydes has been observed to be potentially competitive with PHA formation in the case of cyclic alkenes ozonolysis in the presence of alcohols (Ziemann, 2003). A similar cyclization reaction for the multifunctional carbonyl hydroperoxides can explain the presence of additional ions not expected from PHA formation.

For cyclododecane, at least two "waves" of chemical development exist in the particle phase (Fig. 10d). Initially, $\mathrm{R}^{+}$ ions associated with the CARBROOH, OHCARBROOH, and DICARBROOH grow in. Then, a series of ions with formulae of the form $\mathrm{C}_{12} \mathrm{H}_{\mathrm{y}} \mathrm{O}_{3}^{+}$, with $y=19,17$, and 15, grow in consecutively. $\mathrm{C}_{12} \mathrm{H}_{19} \mathrm{O}_{3}^{+}$at $\mathrm{m} / z 211$ and $\mathrm{C}_{12} \mathrm{H}_{17} \mathrm{O}_{3}^{+}$ at $\mathrm{m} / \mathrm{z} 209$ could correspond with the OHDICARBROOH 


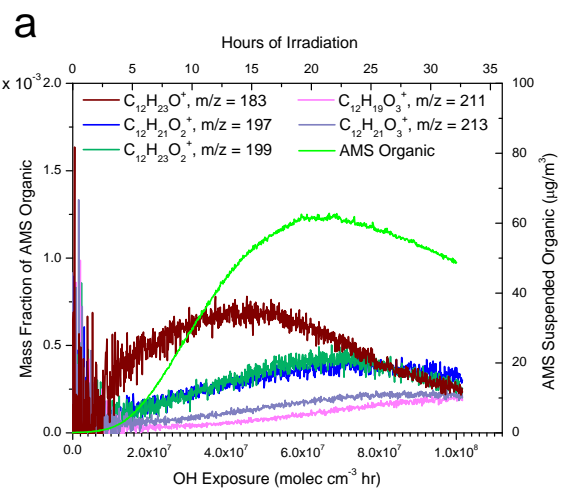

C

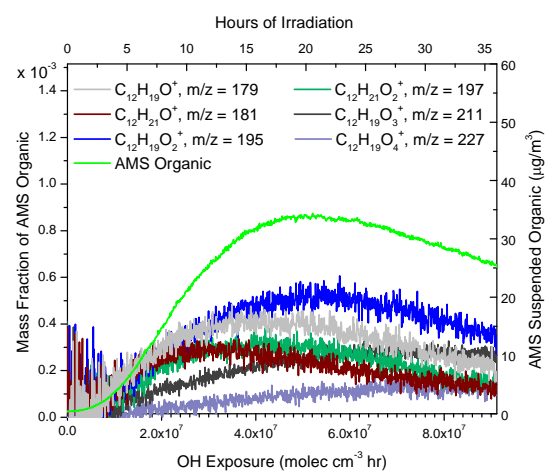

b

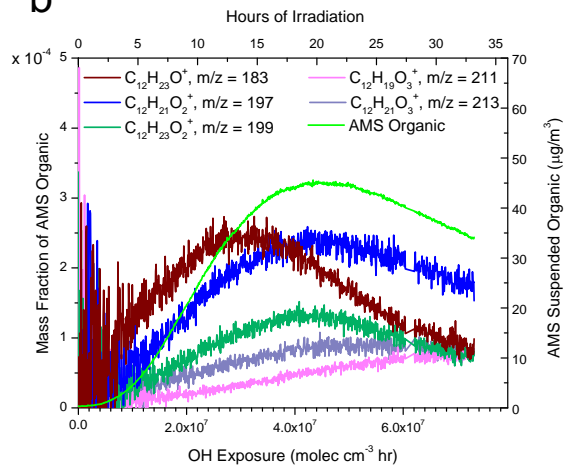

d

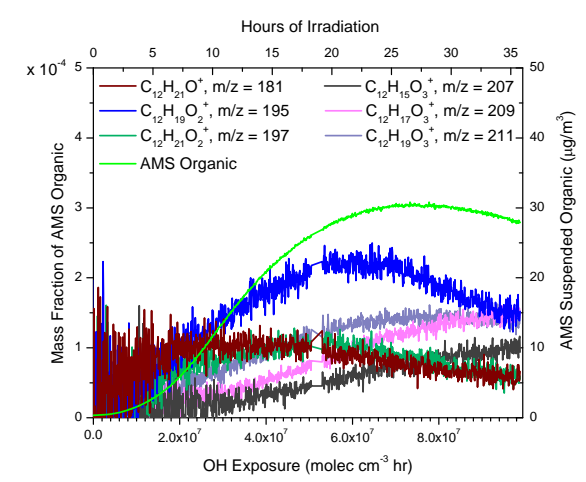

Fig. 10. Characteristic ions in (a) $n$-dodecane, (b) 2-methylundecane, (c) hexylcyclohexane, and (d) cyclododecane aerosol measured by the AMS.

and TRICARBROOH $\mathrm{R}^{+}$ions, respectively. Note that the $\mathrm{C}_{12} \mathrm{H}_{19} \mathrm{O}_{3}^{+}$ion can also result from a ring-opened TRICAR$\mathrm{BROOH}$ (same as in the linear case), but where at least one of the carbonyl groups is presumably an aldehyde. The $\mathrm{C}_{12} \mathrm{H}_{15} \mathrm{O}_{3}^{+}$at $m / z 207$ implies yet another step achieving one fewer degree of saturation. This was characteristic of many of the ions in the cyclododecane AMS mass spectra achieving one additional degree of unsaturation compared to that of hexylcyclohexane and two compared to the non-cyclic systems. This ion assignment is uncertain, though it could correspond with a structure containing a hydroxy, four ketone groups, and a hydroperoxy group with the ring intact (OH4CARBROOH). There may be additional cyclizations or dehydration reactions in the particle phase and/or additional ionization patterns in the AMS that may more feasibly explain the presence of this ion. This is especially relevant when considering the ions of the form $\mathrm{C}_{12} \mathrm{H}_{\mathrm{y}} \mathrm{O}_{\mathrm{z}}^{+}$, with $y=19$, 17 , and 15 and $z=3,4,5$. For the OH4CARBROOH, TRICARBROOH, and OHDICARBROOH, the mass spectrum (Fig. 7) indicates a greater fraction of organic aerosol due to the corresponding $z=4$ ions compared to the $z=5$ ions. This may indicate competitive cyclization over PHA formation, as shown in Schemes 4 (TRICARBROOH) and 5 (OHDICARBROOH) of Fig. 2.

\subsubsection{AMS elemental ratios}

The Van Krevelen diagram, originally used for showing how $\mathrm{O}: \mathrm{C}$ and $\mathrm{H}$ : C elemental ratios change during coal formation (Van Krevelen, 1950), has been recently utilized with HRTOF-AMS data to aid in the interpretation of elemental ratio changes in organic aerosol formation (Heald et al., 2010; $\mathrm{Ng}$ et al., 2011; Chhabra et al., 2011; Lambe et al., 2011, 2012). The slopes on the diagram of $\mathrm{O}: \mathrm{C}$ versus $\mathrm{H}: \mathrm{C}$ can provide insight into the chemical evolution of the aerosol in terms of functional group changes. A slope of -1 for ambient and laboratory data is consistent with carboxylic acid groups without fragmentation (Heald et al., 2010). Ng et al. (2011) showed that, for aged ambient organic aerosol, the slope of -0.5 is consistent with carboxylic acid addition with fragmentation. Both of these results highlighted aerosol that was already quite oxidized, with most of the $\mathrm{O}: \mathrm{C}$ values greater than 0.30. Lambe et al. (2012) presented SOA results from a potential aerosol mass (PAM) chamber in which long-chain alkane SOA O:C extended from a value of 0 to close to 1.4. The Van Krevelen slope from an $\mathrm{O}: \mathrm{C}$ of 0 to approximately 0.3 was -1.3 , and for $\mathrm{O}: \mathrm{C}$ values greater than 0.3 the slope became less negative with a value of -0.7 . Lambe et al. (2012) attribute this change in slope to a transition from a functionalized- to fragment-dominated regime. 


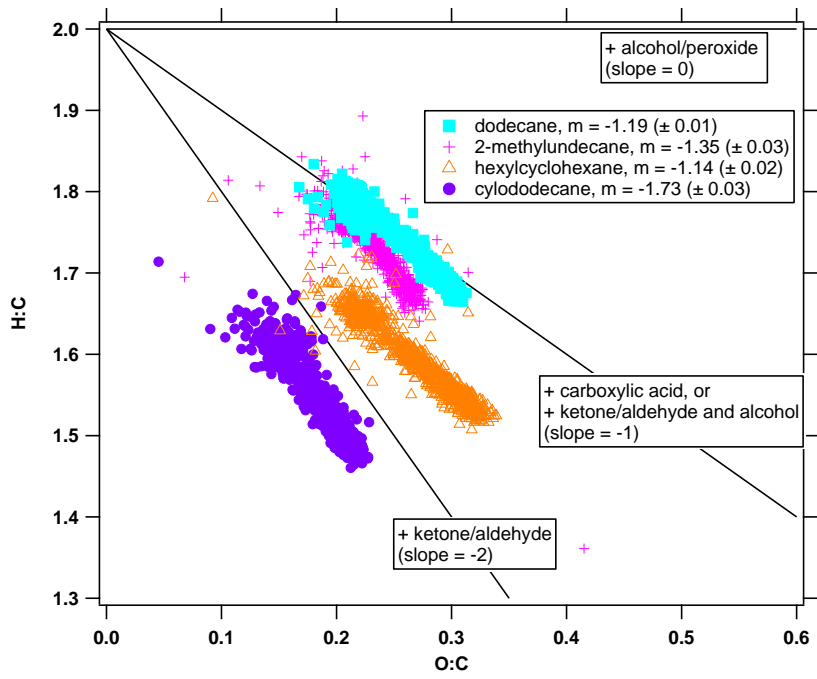

Fig. 11. Van Krevelen diagram for low- $\mathrm{NO}_{\mathrm{x}}$ photooxidation of n-dodecane, 2-methylundecane, hexylcyclohexane, and cyclododecane.

The elemental ratios from the current study are shown in Fig. 11. The experimental progression for all four systems is from upper left to lower right across the Van Krevelen space. All of the compounds have $\mathrm{O}: \mathrm{C}<0.3$, except for the end of the hexylcyclohexane experiment. In increasing order, the slopes are $-1.73,-1.35,-1.19$, and -1.14 for cyclododecane, 2-methylundecane, dodecane, and hexylcyclohexane, respectively. In the presence of $\mathrm{NO}_{\mathrm{x}}$, Tkacik et al. (2012) found steeper slopes (approaching -2) for the same or comparable in structure alkane species, attributed to a combination of carboxylic acid addition and added ketone and alcohol moieties. This was also achieved under a much lower total $\mathrm{OH}$ exposure $\left(\sim 6 \times 10^{6} \mathrm{molec} \mathrm{cm}^{-3} \mathrm{~h}\right)$ than that used in the current experiments, providing contrast between the more efficiently (in terms of $\mathrm{OH}$ exposure) achieved higher $\mathrm{O}: \mathrm{C}$ ratios with fragmentation pathways in the presence of $\mathrm{NO}_{\mathrm{x}}$ compared to the proposed functionalization and accretion schemes in the low- $\mathrm{NO}_{\mathrm{x}}$ regime presented here. In comparison to the average slope of -1.3 in the $\mathrm{O}: \mathrm{C}$ range 0 to 0.3 from $\mathrm{OH}$-initiated oxidation of alkanes in the absence of $\mathrm{NO}_{\mathrm{x}}$ by Lambe et al. (2012), many of the systems here show comparable behavior. The fact that many do not reach an $\mathrm{O}: \mathrm{C}$ much higher than 0.3 with a less negative slope as observed in Lambe et al. (2012) is also consistent with these experiments remaining in the functionalized-dominated regime, and not having yet transitioned to a fragment-dominated regime.

This functionalized-dominated regime is supported by the proposed chemical mechanisms and AMS ions found in each system. Cyclododecane SOA has the slope closest to -2 , indicating a greater contribution from ketone and aldehyde groups. This is consistent with the $\mathrm{C}_{12} \mathrm{H}_{\mathrm{y}} \mathrm{O}_{3}^{+}$ion series in Fig. 10d and the relatively higher degrees of unsaturation in the cyclododecane AMS mass spectrum (Fig. 7) as compared to the other systems.

2-methylundecane SOA exhibits a lower $\mathrm{O}: \mathrm{C}$ than that from $n$-dodecane, supported by the lower fraction of total organic aerosol attributed to oxidized ions compared to $n$ dodecane. $n$-Dodecane achieves the second highest $\mathrm{O}: \mathrm{C}$ for the $\mathrm{OH}$ exposures in this study, and while the progression of key $>150$ amu ions in this system (Fig. 10a) is more gradual, there is continued oxygenation, as observed by the presence of the $\mathrm{C}_{12} \mathrm{H}_{19} \mathrm{O}_{5}^{+}$ion. Yee et al. (2012) also found the $\mathrm{O}: \mathrm{C}$ range to be consistent with the $\mathrm{O}: \mathrm{C}$ of several of the multifunctional hydroperoxides and their derived PHAs.

The higher O:C achieved for hexylcyclohexane may be a result of the generally faster chemistry seen in both the gas-phase oxidation and the particle-phase development, in which initial key ions in the particle phase (Fig. 10c) peak earlier in terms of $\mathrm{OH}$ exposure $<5 \times 10^{7} \mathrm{molec} \mathrm{cm}^{-3} \mathrm{~h}$ as compared to those of the other systems. This could be a result of verging on increased contribution from fragmentation processes increasing the $\mathrm{O}: \mathrm{C}$ or oxygenation achieved from continued oxidation.

\section{Conclusions}

We address here the mechanisms of formation of SOA in alkane systems under low- $\mathrm{NO}_{\mathrm{x}}$ conditions. Special attention is given to the effect of alkane structure on SOA formation and to the molecular identifications of the oxidation products responsible for SOA growth. Aerosol formation from the photooxidation of $n$-dodecane, 2-methylundecane, hexylcyclohexane, and cyclododecane under low- $\mathrm{NO}_{\mathrm{x}}$ conditions is initiated by the partitioning of a 2nd-generation product, the carbonyl hydroperoxide (CARBROOH), to the particle phase. It appears that this hydroperoxide is incorporated with simultaneous formation of a peroxyhemiacetal. Several other multifunctional hydroperoxides are proposed to explain characteristic ions in the AMS mass spectra for each system, suggesting that at least three additional degrees of unsaturation might be achieved for cyclododecane while functionalizing primarily via ketone/aldehyde addition.

2-methylundecane exhibits the least extent of chemical processing in the particle phase (in terms of the least variety of $\mathrm{C}_{\mathrm{x}} \mathrm{H}_{\mathrm{y}} \mathrm{O}_{\mathrm{z}}^{+}$ions observed in the mass spectra) relative to the other systems, likely a result of gas-phase fragmentation that leads to a product distribution consisting of relatively higher volatility intermediates. Hexylcyclohexane exhibits rapid gas-phase oxidation and particle-phase processing reflected in the highest achieved $\mathrm{O}: \mathrm{C}$ (verging on 0.4). Of the systems studied, hexylcyclohexane behaves in terms of SOA chemistry as a hybrid of the other systems. It exhibits the rapid formation of functionalized semi- and lowvolatility species that contribute to the particle phase, but then fragmentation processes (attributable to the branching) start to dominate and lower the relative particle mass due to 
$\mathrm{C}_{12}$ oxygenates. Cyclization processes analogous to cyclic hemiacetal and higher volatility dihydrofuran formation can also contribute to limitations in particle growth.

While the $>150$ amu tracer ions in the AMS help to identify potential species involved in particle-phase chemistry like PHA formation, the more oxidized and functionalized the ion, the greater potential exists for multiple ionization and fragmentation schemes in the AMS. Ideally, standards of different structure but analogous functionality would be available for generating mass spectral standards that can be used to better interpret the mass spectra in this region. Ionization schemes need to be better elucidated to see if observed ions can be explained by particle-phase chemistry that involves species of cyclic structure and/or those undergoing cyclization followed by dehydration. Such schemes were proposed here to explain additional ions in the AMS not expected purely from PHA formation. This is relevant for determining the molecular identity of some of the highly oxygenated $\left(>\mathrm{O}_{3}^{+}\right)$ions that grow in the particle phase at extended $\mathrm{OH}$ exposures.

Evidence for additional particle-phase reactions including cyclization of multifunctional hydroperoxides exists. Intramolecular cyclization of multifunctional hydroperoxides can be competitive with the intermolecular reaction of multifunctional hydroperoxides with aldehydes to form PHAs. For the functional groups presumed to be incorporated via the gas-phase mechanisms ketone (some aldehyde for cyclododecane), hydroperoxy, and hydroxyl, it is very likely these functional groups undergo intramolecular, as well as intermolecular, reactions (including oligomer formation), depending on their relative positions on the $\mathrm{C}_{12}$ backbone. This may be highly relevant for hexylcyclohexane in which the alkyl branch is sufficiently long to still cyclize and result in a bicyclic structure. Cyclododecane may ring open to form functionalized aldehydes and then cyclize again (not necessarily returning to a $\mathrm{C}_{12}$ ring).

Environmental factors such as humidity, aerosol acidity, and temperature are likely to play a role in controlling these chemical transformations and ultimately impact the extent of PHA formation. The present study was conducted under dry conditions, but future study would benefit from examining the role of humidity as aqueous particles will affect partitioning of certain species. Parameterizations of 1-tetradecene ozonolysis experiments found that the organic hydroperoxides and peroxides made up the majority of the aerosol mass under humid conditions (Tobias et al., 2000). Tobias et al. (2000) also calculated using these parameterizations that, for an organic aerosol loading $\sim 10 \mu \mathrm{g} \mathrm{m}^{3}$, the generated hydroperoxides and peroxides would be expected to be completely in the particle phase. Further, aldehyde contribution to the particle phase has been found to be enhanced with aerosol acidity (Jang et al., 2002). DePalma et al. (2013) also found that dimers formed from $\alpha$-pinene ozonolysis products, including a PHA, return to the monomers with increases in temperature from $298 \mathrm{~K}$ to $373 \mathrm{~K}$. Additional simulations in DePalma et al. (2013) also suggest that, for the PHA structure considered, the dimerization free energy is favorable for formation in the gas-phase as well as in water-, methanol-, and acetonitrile-like solutions. This was found to be unique to the PHA structure considered, as other dimerization reactions were not as broadly favorable among the different solution types. The potential for dimerization in the gas phase has implications for new particle formation as well. While the experiments employed here were seeded, and it seems that initial organic growth may be initiated by PHA incorporation to the particle phase, it has been generally assumed that PHA reactions occur in the particle phase. This is supported by simulations in Shiraiwa et al. (2013) for the case of $n$-dodecane, though it may also be that the phase of reaction depends on the precursor system and the structure of its oxidation products.

The systematic study of these $\mathrm{C}_{12}$ structures lays a chemical groundwork for understanding the dynamics of particle growth concerted with particle-phase reactions (e.g., PHA formation) and sustained growth via semi-volatile and lowvolatile product partitioning, followed by additional particlephase oxidation if unhampered by fragmentation processes. Further study of the $\mathrm{C}_{12}$ system should include additional isomeric configurations of branching and cyclic + branched structures to better understand the spectrum of oxidation pathways between 2-methlyundecane and hexylcyclohexane and between hexylcyclohexane and cyclododecane. These structural dependencies will certainly impact the mechanisms of SOA formation and SOA yields, which can affect the representation of SOA formation from alkanes in atmospheric modeling.

\section{Supplementary material related to this article is available online at http://www.atmos-chem-phys.net/13/ 11121/2013/acp-13-11121-2013-supplement.pdf.}

Acknowledgements. This work was supported by the Office of Science (Biological and Environmental Research), US Department of Energy Grant (DE-SC 0006626), and National Science Foundation Grants AGS-1057183 and ATM-0650061. The authors acknowledge helpful discussions with John D. Crounse and Jason M. St. Clair regarding treatment of CIMS data and gas-phase data, as well as experimental assistance and discussions with Reddy L. N. Yatavelli and ManNin Chan. L. D. Yee, J. S. Craven, and C. L. Loza were supported by National Science Foundation Graduate Research Fellowships.

Edited by: J. Liggio 


\section{References}

Aiken, A. C., DeCarlo, P. F., and Jimenez, J. L.: Elemental analysis of organic species with electron ionization high-resolution mass spectrometry, Anal. Chem., 79, 8350-8358, 2007.

Aiken, A. C., Decarlo, P. F., Kroll, J. H., Worsnop, D. R., Huffman, J. A., Docherty, K. S., Ulbrich, I. M., Mohr, C., Kimmel, J. R., Sueper, D., Sun, Y., Zhang, Q., Trimborn, A., Northway, M., Ziemann, P. J., Canagaratna, M. R., Onasch, T. B., Alfarra, M. R., Prevot, A. S. H., Dommen, J., Duplissy, J., Metzger, A., Baltensperger, U., and Jimenez, J. L.: O/C and OM/OC ratio of primary, secondary, and ambient organic aerosols with high-resolution time-of-flight aerosol mass spectrometry, Environ. Sci. Technol., 42, 4478-4485, 2008.

Allan, J. D., Delia, A. E., Coe, H., Bower, K. N., Alfarra, M. R., Jimenez, J. L., Middlebrook, A. M., Drewnick, F., Onasch, T. B., Canagaratna, M. R., Jayne, J. T., and Worsnop, D. R.: A generalised method for the extraction of chemically resolved mass spectra from aerodyne aerosol mass spectrometer data, J. Aerosol Sci., 35, 909-922, 2004.

Aschmann, S. M., Arey, J., and Atkinson, R.: Kinetics and products of the gas-phase reaction of $\mathrm{OH}$ radicals with 5-hydroxy2-pentanone at 296士 2 k, J. Atmos. Chem., 45, 289-299, doi:10.1023/A:1024216900051, 2003.

Atkinson, R.: Gas-phas tropospheric chemistry of organic compounds, J. Phys. Chem. Ref. Data, Monogr., 2, 1-216, 1994.

Atkinson, R.: Gas-phase tropospheric chemistry of volatile organic compounds. 1. Alkanes and alkenes, J. Phys. Chem. Ref. Data, 26, 215-290, 1997.

Atkinson, R. and Arey, J.: Atmospheric degradation of volatile organic compounds, Chem. Rev., 103, 4605-4638, doi:10.1021/cr0206420, 2003.

Atkinson, R., Arey, J., and Aschmann, S. M.: Atmospheric chemistry of alkanes: Review and recent developments, Atmos. Environ., 42, 5859-5871, doi:10.1016/j.atmosenv.2007.08.040, 2008.

Aumont, B., Valorso, R., Mouchel-Vallon, C., Camredon, M., LeeTaylor, J., and Madronich, S.: Modeling SOA formation from the oxidation of intermediate volatility n-alkanes, Atmos. Chem. Phys., 12, 7577-7589, doi:10.5194/acp-12-7577-2012, 2012.

Bahreini, R., Middlebrook, A. M., de Gouw, J. A., Warneke, C., Trainer, M., Brock, C. A., Stark, H., Brown, S. S., Dube, W. P., Gilman, J. B., Hall, K., Holloway, J. S., Kuster, W. C., Perring, A. E., Prevot, A. S. H., Schwarz, J. P., Spackman, J. R., Szidat, S., Wagner, N. L., Weber, R. J., Zotter, P., and Parrish, D. D.: Gasoline emissions dominate over diesel in formation of secondary organic aerosol mass, Geophys. Res. Lett., 39, L06805, doi:10.1029/2011GL050718, 2012.

Benson, S. W.: Thermochemical kinetics, Wiley, second edn., 1976. Canagaratna, M., Jayne, J., Jimenez, J., Allan, J., Alfarra, M., Zhang, Q., Onasch, T., Drewnick, F., Coe, H., Middlebrook, A., Delia, A., Williams, L., Trimborn, A., Northway, M., DeCarlo, P., Kolb, C., Davidovits, P., and Worsnop, D.: Chemical and microphysical characterization of ambient aerosols with the Aerodyne aerosol mass spectrometer, Mass Spectrom. Rev., 26, 185-222, doi:10.1002/mas.20115, 2007.

Capouet, M., Mueller, J. F., Ceulemans, K., Compernolle, S., Vereecken, L., and Peeters, J.: Modeling aerosol formation in alpha-pinene photo-oxidation experiments, J. Geophys. Res.Atmos., 113, D02308, doi:10.1029/2007JD008995, 2008.
Cappa, C. D., Zhang, X., Loza, C. L., Craven, J. S., Yee, L. D., and Seinfeld, J. H.: Application of the statistical oxidation model (SOM) to secondary organic aerosol formation from photooxidation of $\mathrm{C}_{12}$ alkanes, Atmos. Chem. Phys., 13, 1591-1606, doi:10.5194/acp-13-1591-2013, 2013.

Chhabra, P. S., Ng, N. L., Canagaratna, M. R., Corrigan, A. L., Russell, L. M., Worsnop, D. R., Flagan, R. C., and Seinfeld, J. H.: Elemental composition and oxidation of chamber organic aerosol, Atmos. Chem. Phys., 11, 8827-8845, doi:10.5194/acp-11-88272011, 2011.

Cocker, D. R., Flagan, R. C., and Seinfeld, J. H.: State-of-the-art chamber facility for studying atmospheric aerosol chemistry, Environ. Sci. Technol., 35, 2594-2601, 2001.

Compernolle, S., Ceulemans, K., and Müller, J.-F.: EVAPORATION: a new vapour pressure estimation methodfor organic molecules including non-additivity and intramolecular interactions, Atmos. Chem. Phys., 11, 9431-9450, doi:10.5194/acp-119431-2011, 2011.

Craven, J. S., Yee, L. D., Ng, N. L., Canagaratna, M. R., Loza, C. L., Schilling, K. A., Yatavelli, R. L. N., Thornton, J. A., Ziemann, P. J., Flagan, R. C., and Seinfeld, J. H.: Analysis of secondary organic aerosol formation and aging using positive matrix factorization of high-resolution aerosol mass spectra: application to the dodecane low- $\mathrm{NO}_{\mathrm{x}}$ system, Atmos. Chem. Phys., 12, 1179511817, doi:10.5194/acp-12-11795-2012, 2012.

Crounse, J. D., McKinney, K. A., Kwan, A. J., and Wennberg, P. O.: Measurement of gas-phase hydroperoxides by chemical ionization mass spectrometry, Anal. Chem., 78, 6726-6732, 2006.

DeCarlo, P. F., Kimmel, J. R., Trimborn, A., Northway, M. J., Jayne, J. T., Aiken, A. C., Gonin, M., Fuhrer, K., Horvath, T., Docherty, K. S., Worsnop, D. R., and Jimenez, J. L.: Field-deployable, high-resolution, time-of-flight aerosol mass spectrometer, Anal. Chem., 78, 8281-8289, 2006.

DePalma, J. W., Horan, A. J., Hall IV, W. A., and Johnston, M. V.: Thermodynamics of oligomer formation: implications for secondary organic aerosol formation and reactivity, Phys. Chem. Chem. Phys., 15, 6935-6944, doi:10.1039/C3CP44586K, 2013.

Dibble, T. S.: Cyclization of 1,4-hydroxycarbonyls is not a homogenous gas phase process, Chem. Phys. Lett., 447, 5-9, doi:10.1016/j.cplett.2007.08.088, 2007.

Docherty, K. S., Wu, W., Lim, Y. B., and Ziemann, P. J.: Contributions of Organic Peroxides to Secondary Aerosol Formed from Reactions of Monoterpenes with $\mathrm{O}_{3}$, Environ. Sci. Technol., 39, 4049-4059, doi:10.1021/es050228s, 2005.

Gao, S., Keywood, M., Ng, N. L., Surratt, J., Varutbangkul, V., Bahreini, R., Flagan, R. C., and Seinfeld, J. H.: Low-molecularweight and oligomeric components in secondary organic aerosol from the ozonolysis of cycloalkenes and alpha-pinene, J. Phys. Chem. A, 108, 10147-10164, 2004a.

Gao, S., Ng, N. L., Keywood, M., Varutbangkul, V., Bahreini, R., Nenes, A., He, J. W., Yoo, K. Y., Beauchamp, J. L., Hodyss, R. P., Flagan, R. C., and Seinfeld, J. H.: Particle phase acidity and oligomer formation in secondary organic aerosol, Environ. Sci. Technol., 38, 6582-6589, 2004b.

Gentner, D. R., Isaacman, G., Worton, D. R., Chan, A. W. H., Dallmann, T. R., Davis, L., Liu, S., Day, D. A., Russell, L. M., Wilson, K. R., Weber, R., Guha, A., Harley, R. A., and Goldstein, A. H.: Elucidating secondary organic aerosol from diesel and gasoline vehicles through detailed characterization 
of organic carbon emissions, Proc. Natl. Acad. Sci. U. S. A., doi:10.1073/pnas.1212272109, 2012.

Heald, C. L., Kroll, J. H., Jimenez, J. L., Docherty, K. S., DeCarlo, P. F., Aiken, A. C., Chen, Q., Martin, S. T., Farmer, D. K., and Artaxo, P.: A simplified description of the evolution of organic aerosol composition in the atmosphere, Geophys. Res. Lett., 37, L08803, doi:10.1029/2010GL042737, 2010.

Isaacman, G., Wilson, K. R., Chan, A. W. H., Worton, D. R., Kimmel, J. R., Nah, T., Hohaus, T., Gonin, M., Kroll, J. H., Worsnop, D. R., and Goldstein, A. H.: Improved resolution of hydrocarbon structures and constitutional isomers in complex mixtures using gas chromatography-vacuum ultraviolet-mass spectrometry, Anal. Chem., 84, 2335-2342, doi:10.1021/ac2030464, 2012.

Jang, M., Czoschke, N. M., Lee, S., and Kamens, R. M.: Heterogeneous Atmospheric Aerosol Production by AcidCatalyzed Particle-Phase Reactions, Science, 298, 814-817, doi:10.1126/science.1075798, 2002.

Jenkin, M. E., Saunders, S. M., and Pilling, M. J.: The tropospheric degradation of volatile organic compounds: a protocol for mechanism development, Atmos. Environ., 31, 81-104, doi:10.1016/S1352-2310(96)00105-7, 1997.

Johnson, D., Jenkin, M., Wirtz, K., and Martin-Reviejo, M.: Simulating the formation of secondary organic aerosol from the photooxidation of aromatic hydrocarbons, Environ. Chem., 2, 35-48, doi:10.1071/EN04079, 2005.

Jordan, C. E., Ziemann, P. J., Griffin, R. J., Lim, Y. B., Atkinson, R., and Arey, J.: Modeling SOA formation from $\mathrm{OH}$ reactions with C8-C17 n-alkanes, Atmos. Environ., 42, 8015-8026, doi:10.1016/j.atmosenv.2008.06.017, 2008.

Kalberer, M.: Identification of polymers as major components of atmospheric organic aerosols, Science, 303, 1659-1662, doi10.1126/science.1092185, 2004.

Kalberer, M., Sax, M., and Samburova, V.: Molecular Size Evolution of Oligomers in Organic Aerosols Collected in Urban Atmospheres and Generated in a Smog Chamber, Environ. Sci. Technol., 40, 5917-5922, doi:10.1021/es0525760, 2006.

Keywood, M. D., Varutbangkul, V., Bahreini, R., Flagan, R. C., and Seinfeld, J. H.: Secondary organic aerosol formation from the ozonolysis of cycloalkenes and related compounds, Environ. Sci. Technol., 38, 4157-4164, 2004.

Kwok, E. S. and Atkinson, R.: Estimation of hydroxyl radical reaction rate constants for gas-phase organic compounds using a structure-reactivity relationship: An update, Atmos. Environ., 29, 1685-1695, doi:10.1016/1352-2310(95)00069-B, 1995.

Lambe, A. T., Onasch, T. B., Massoli, P., Croasdale, D. R., Wright, J. P., Ahern, A. T., Williams, L. R., Worsnop, D. R., Brune, W. H., and Davidovits, P.: Laboratory studies of the chemical composition and cloud condensation nuclei $(\mathrm{CCN})$ activity of secondary organic aerosol (SOA) and oxidized primary organic aerosol (OPOA), Atmos. Chem. Phys., 11, 8913-8928, doi:10.5194/acp11-8913-2011, 2011.

Lambe, A. T., Onasch, T. B., Croasdale, D. R., Wright, J. P., Martin, A. T., Franklin, J. P., Massoli, P., Kroll, J. H., Canagaratna, M. R., Brune, W. H., Worsnop, D. R., and Davidovits, P.: Transitions from functionalization to fragmentation reactions of laboratory secondary organic aerosol (SOA) generated from the $\mathrm{OH}$ oxidation of alkane precursors, Environ. Sci. Technol., 46, 5430-5437, doi:10.1021/es300274t, 2012.
Lim, Y. B. and Ziemann, P. J.: Products and mechanism of secondary organic aerosol formation from reactions of n-alkanes with $\mathrm{OH}$ radicals in the presence of $\mathrm{NO}_{\mathrm{x}}$, Environ. Sci. Technol., 39, 9229-9236, doi:10.1021/es051447g, 2005.

Lim, Y. B. and Ziemann, P. J.: Effects of molecular structure on aerosol yields from $\mathrm{OH}$ radical-initiated reactions of linear, branched, and cyclic alkanes in the presence of $\mathrm{NO}_{\mathrm{x}}$, Environ. Sci. Technol., 43, 2328-2334, doi:10.1021/es803389s, 2009a.

Lim, Y. B. and Ziemann, P. J.: Chemistry of secondary organic aerosol formation from $\mathrm{OH}$ radical-initiated reactions of linear, branched, and cyclic alkanes in the presence of $\mathrm{NO}_{\mathrm{x}}$, Aerosol Sci. Technol., 43, 604-619, doi:10.1080/02786820902802567, 2009b.

Lim, Y. B. and Ziemann, P. J.: Kinetics of the heterogeneous conversion of 1,4-hydroxycarbonyls to cyclic hemiacetals and dihydrofurans on organic aerosol particles, Phys. Chem. Chem. Phys., 11, 8029-8039, doi:10.1039/B904333K, 2009c.

Lipsky, E. M. and Robinson, A. L.: Effects of dilution on fine particle mass and partitioning of semivolatile organics in diesel exhaust and wood smoke, Environ. Sci. Technol., 40, 155-162, 2006.

Nakao, S., Shrivastava, M., Nguyen, A., Jung, H., and Cocker, D.: Interpretation of secondary organic aerosol formation from diesel exhaust photooxidation in an environmental chamber, Aerosol Sci. Technol., 45, 964-972, doi:10.1080/02786826.2011.573510, 2011.

Ng, N. L., Canagaratna, M. R., Jimenez, J. L., Chhabra, P. S., Seinfeld, J. H., and Worsnop, D. R.: Changes in organic aerosol composition with aging inferred from aerosol mass spectra, Atmos. Chem. Phys., 11, 6465-6474, doi:10.5194/acp-11-64652011, 2011.

Paulot, F., Crounse, J. D., Kjaergaard, H. G., Kroll, J. H., Seinfeld, J. H., and Wennberg, P. O.: Isoprene photooxidation: new insights into the production of acids and organic nitrates, Atmos. Chem. Phys., 9, 1479-1501, 1680-7316, 2009.

Presto, A. A., Miracolo, M. A., Kroll, J. H., Worsnop, D. R., Robinson, A. L., and Donahue, N. M.: Intermediate-volatility organic compounds: a potential source of ambient oxidized organic aerosol, Environ. Sci. Technol., 43, 4744-4749, doi:10.1021/es803219q, 2009.

Presto, A. A., Miracolo, M. A., Donahue, N. M., and Robinson, A. L.: Secondary organic aerosol formation from high- $\mathrm{NO}_{\mathrm{X}}$ photo-oxidation of low volatility precursors: n-alkanes, Environ. Sci. Technol., 44, 2029-2034, doi:10.1021/es903712r, 2010.

Pye, H. O. T. and Pouliot, G. A.: Modeling the role of alkanes, polycyclic aromatic hydrocarbons, and their oligomers in secondary organic aerosol formation, Environ. Sci. Technol., 46, 6041-6047, doi:10.1021/es300409w, 2012.

Robinson, A. L., Donahue, N. M., Shrivastava, M. K., Weitkamp, E. A., Sage, A. M., Grieshop, A. P., Lane, T. E., Pierce, J. R., and Pandis, S. N.: Rethinking organic aerosols: Semivolatile emissions and photochemical aging, Science, 315, 1259-1262, 2007.

Sato, K., Hatakeyama, S., and Imamura, T.: Secondary organic aerosol formation during the photooxidation of toluene: $\mathrm{NO}_{\mathrm{x}}$ dependence of chemical composition, J. Phys. Chem. A, 111, 9796-9808, doi:10.1021/jp071419f, 2007.

Schauer, J. J., Kleeman, M. J., Cass, G. R., and Simoneit, B. R. T.: Measurement of emissions from air pollution sources. 2. C1 through $\mathrm{C} 30$ organic compounds from medium 
duty diesel trucks, Environ. Sci. Technol., 33, 1578-1587, doi:10.1021/es980081n, 1999.

Schauer, J. J., Kleeman, M. J., Cass, G. R., and Simoneit, B. R. T.: Measurement of emissions from air pollution sources. 5. C1C32 organic compounds from gasoline-powered motor vehicles, Environ. Sci. Technol., 36, 1169-1180, doi:10.1021/es0108077, 2002.

Shiraiwa, M., Yee, L. D., Schilling, K. A., Loza, C. L., Craven, J. S., Zuend, A., Ziemann, P. J., and Seinfeld, J. H.: Size distribution dynamics reveal particle-phase chemistry in organic aerosol formation, Proc. Natl. Acad. Sci., 110, 11746-11750, doi:10.1073/pnas.1307501110, 2013.

St. Clair, J. M., McCabe, D. C., Crounse, J. D., Steiner, U., and Wennberg, P. O.: Chemical ionization tandem mass spectrometer for the in situ measurement of methyl hydrogen peroxide, Rev. Sci. Instrum., 81, 094102, doi:10.1063/1.3480552, 2010.

Surratt, J. D., Kroll, J. H., Kleindienst, T. E., Edney, E. O., Claeys, M., Sorooshian, A., Ng, N. L., Offenberg, J. H., Lewandowski, M., Jaoui, M., Flagan, R. C., and Seinfeld, J. H.: Evidence for organosulfates in secondary organic aerosol, Environ. Sci. Technol., 41, 517-527, times Cited: 33, 2007.

Surratt, J. D., Chan, A. W. H., Eddingsaas, N. C., Chan, M. N., Loza, C. L., Kwan, A. J., Hersey, S. P., Flagan, R. C., Wennberg, P. O., and Seinfeld, J. H.: Reactive intermediates revealed in secondary organic aerosol formation from isoprene, Proc. Natl. Acad. Sci. USA, 107, 6640-6645, 2010.

Tkacik, D. S., Presto, A. A., Donahue, N. M., and Robinson, A. L.: Secondary organic aerosol formation from intermediate-volatility organic compounds: cyclic, linear, and branched alkanes, Environ. Sci. Technol., 46, 8773-8781, doi:10.1021/es301112c, 2012.
Tobias, H. J. and Ziemann, P. J.: Thermal Desorption Mass Spectrometric Analysis of Organic Aerosol Formed from Reactions of 1-Tetradecene and $\mathrm{O}_{3}$ in the Presence of Alcohols and Carboxylic Acids, Environ. Sci. Technol., 34, 2105-2115, doi:10.1021/es9907156, 2000.

Tobias, H. J., Docherty, K. S., Beving, D. E., and Ziemann, P. J.: Effect of Relative Humidity on the Chemical Composition of Secondary Organic Aerosol Formed from Reactions of 1-Tetradecene and $\mathrm{O}_{3}$, Environ. Sci. Technol., 34, 2116-2125, doi:10.1021/es991057s, 2000.

Van Krevelen, D. W.: Graphical-statistical method for the study of structure and reaction processes of coal, Fuel, 24, 269-284, 1950.

Yee, L. D., Craven, J. S., Loza, C. L., Schilling, K. A., Ng, N. L., Canagaratna, M. R., Ziemann, P. J., Flagan, R. C., and Seinfeld, J. H.: Secondary organic aerosol formation from low- $\mathrm{NO}_{\mathrm{x}}$ photooxidation of dodecane: evolution of multigeneration gasphase chemistry and aerosol composition, J. Phys. Chem. A, 116, 6211-6230, doi:10.1021/jp211531h, 2012.

Zhang, X. and Seinfeld, J. H.: A functional group oxidation model (FGOM) for SOA formation and aging, Atmos. Chem. Phys., 13, 5907-5926, doi:10.5194/acp-13-5907-2013, 2013.

Ziemann, P. J.: Formation of alkoxyhydroperoxy aldehydes and cyclic peroxyhemiacetals from reactions of cyclic alkenes with $\mathrm{O}_{3}$ in the presence of alcohols, J. Phys. Chem. A, 107, 20482060, doi:10.1021/jp022114y, 2003. 